http://dx.doi.org/10.5800/GT-2014-5-1-0124

\title{
GEOLOGICAL MEDIUM AND UNDERGROUND HYDROSPHERE
}

\author{
S. V. Alekseev, E. A. Kozyreva \\ Institute of the Earth's Crust SB RAS, Irkutsk, Russia
}

\begin{abstract}
The article informs about the history, the staff, researches and scientific activities of the Laboratory of Hydrogeology and the Laboratory of Engineering Geology and Geoecology of the Institute of the Earth's Crust, SB RAS. It reviews the major results of scientific research projects implemented from 2009 to 2013, which provided for determination of characteristics of the geological medium and hydrosphere of East Siberia and Mongolia in natural and technogenic conditions and modeling of the evolution of natural, natural-technogenic hydrogeological and engineering geological systems in regions with contrasting climate conditions and specific geological settings.
\end{abstract}

Key words: underground hydrosphere, mineral, thermal, industrial underground water, hydrogeological systems, stable isotopes, geological medium, natural-technogenic systems, exogenic geological processes, East Siberia, Mongolia.

Citation: Alekseev S.V., Kozyreva E.A. 2014. Geological medium and underground hydrosphere. Geodynamics \& Tectonophysics 5 (1), 201-221. doi:10.5800/GT-2014-5-1-0124.

\section{ГЕОЛОГИЧЕСКАЯ СРЕДА И ПОДЗЕМНАЯ ГИДРОСФЕРА}

\section{С. В. Алексеев, Е. А. Козырева}

\section{Институт земной коры СО РАН, Иркутск, Россия}

Аннотация: В настоящей статье представлены материалы по истории, кадровому составу, научной и научно-организационной деятельности лаборатории гидрогеологии и лаборатории инженерной геологии и геоэкологии Института земной коры СО РАН. Основная часть статьи посвящена результатам научно-исследовательских работ 20092013 гг., позволившим охарактеризовать состояние геологической среды и подземной гидросферы Восточной Сибири и Монголии в природных и техногенных условиях, а также создать модели эволюции природных, природно-техногенных гидрогеологических и инженерно-геологических систем в регионах с контрастными климатическими условиями и геолого-структурной обстановкой.

Ключевые слова: подземная гидросфера, минеральные, термальные, промышленные подземные воды, гидрогеологические системы, стабильные изотопы, геологическая среда, природно-технические системы, экзогенные геологические процессы, Восточная Сибирь, Монголия. 


\section{1. ВВЕДЕНИЕ}

Геологическая среда - открытая иерархически устроенная термодинамическая система. Являясь важнейшим элементом литосферы, она определяет жизнедеятельность человека и биосферы в целом.

Состояние геологической среды - важнейший параметр, интегрирующий результаты воздействия различных природных и техногенных факторов. Эволюционируя, оно стремится к равновесию с изменяющейся во времени внешней средой. При этом происходит цепь взаимосвязанных процессов трансформации компонентов геологической среды - горных пород, подземных вод, природных газов, биоты, физических полей и т.д. Расширение и углубление знаний об особенностях эволюции геологической среды дает определенный ключ к пониманию важнейших функций литосферы - ресурсной, геодинамической, геохимической. Энергетика системы вода-порода-газ-живое вещество

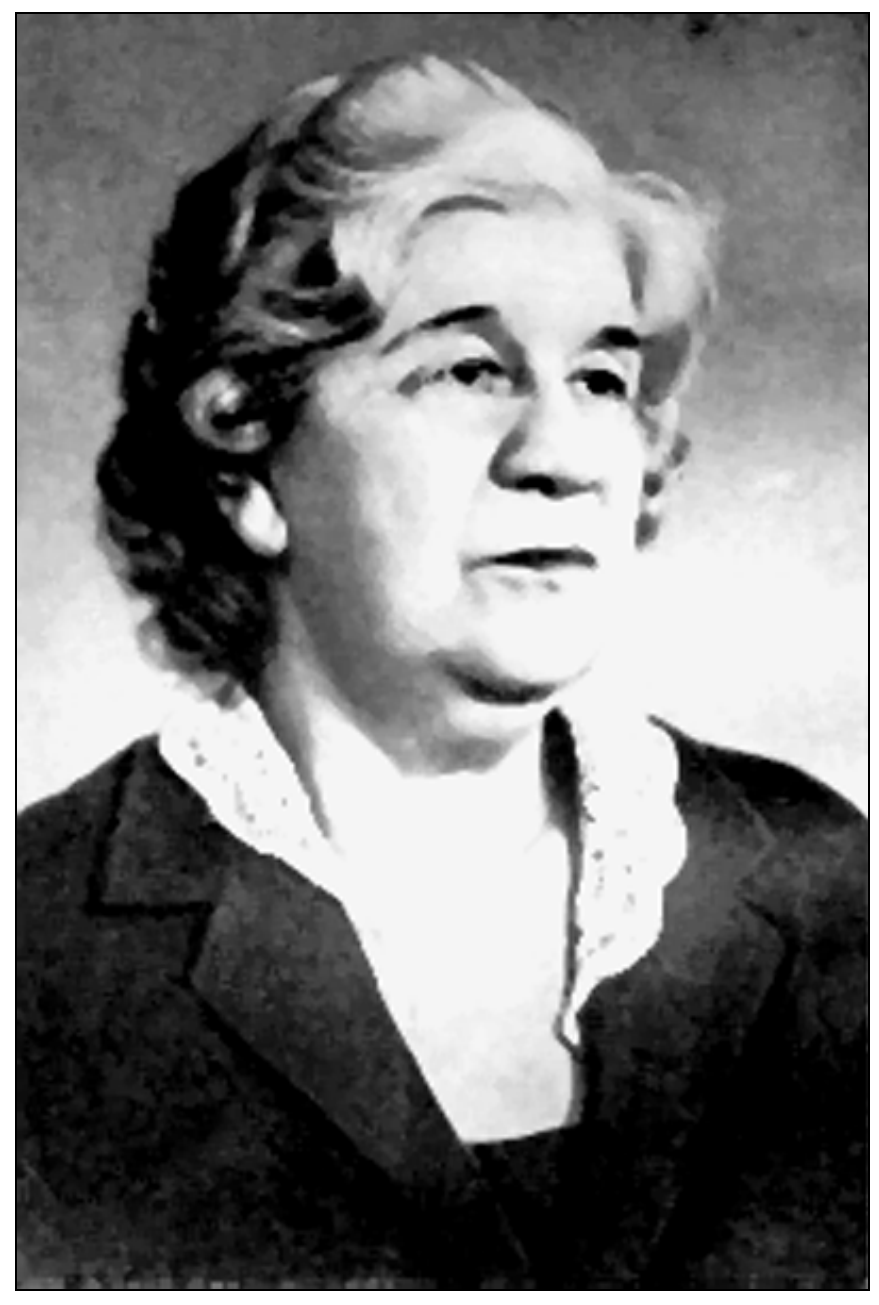

Рис. 1. Д. г.-м. н., профессор В.Г. Ткачук.

Fig. 1. Prof. Tkachuk V.G., Doctor of Geology and Mineralogy. и массообмен в ее границах - сущность направления мировых исследований XXI в.

Отдел гидрогеологии и инженерной геологии под руководством д.г.-м.н. С.В. Алексеева многие годы выполняет научно-исследовательские работы по одному из основных направлений деятельности Института земной коры СО РАН - «Ресурсы, динамика подземных вод и геоэкология». Отдел включает лабораторию гидрогеологии (зав. лаб. д.г.-м.н. С.В. Алексеев) и лабораторию инженерной геологии и геоэкологии (зав. лаб. к.г.-м.н. Е.А. Козырева).

\section{2. ПРИРОДНЫЕ И ТЕХНОГЕННЫЕ ПРОЦЕССЫ В ПОДЗЕМНОЙ ГИДРОСФЕРЕ ВОСТОЧНОЙ СИБИРИ}

\section{1. КРАТКАЯ ИСТОРИЧЕСКАЯ СПРАВКА}

Лаборатория гидрогеологии основана в 1953 г. доктором геолого-минералогических наук, профессором Валентиной Георгиевной Ткачук (рис. 1). Создание лаборатории явилось началом систематических исследований подземной гидросферы Восточной Сибири.

На первом этапе (1953-1960 гг.) осуществлялись региональные исследования, гидрогеологическое картирование и изучение минеральных вод. С 1961 по 1979 г. (заведующий Е.В. Пиннекер) решались проблемы генезиса и формирования различных геохимических типов подземных вод, в т.ч. концентрированных рассолов, развивалось учение о подземном стоке, проводились научно-прикладные исследования гидрогеологических условий зоны БАМ. Из других направлений следует выделить гидрогеологию месторождений полезных ископаемых, поиски месторождений минеральных и пресных подземных вод и изотопную гидрогеологию.

С 1979 по 1995 г. действовали две лаборатории гидрогеологического профиля по руководством чл.корр. РАН, проф. Е.В. Пиннекера и д.г.-м.н., проф. Б.И. Писарского (рис. 2). В 1995 г. они объединены в одну структурную единицу. Главным направлением исследований этих лет стало выявление роли воды в геологических процессах и изучение закономерностей формирования подземных вод.

Важнейшим достижением Е.В. Пиннекера и его коллег стала шеститомная монография «Основы гидрогеологии», не имеющая аналогов в России и за рубежом. Два тома этого уникального труда были переизданы в Англии и Германии. Е.В. Пиннекер, Б.И. Писарский и И.С. Ломоносов были удостоены Государственной премии СССР в области науки и техники. Полученные важнейшие научные результаты позволили гидрогеологам института прочно закрепиться на мировом уровне.

В 2001 г. лабораторию возглавил ученик и последователь Е.В. Пиннекера С.В. Алексеев. В настоящее время в штате структурной единицы института 18 

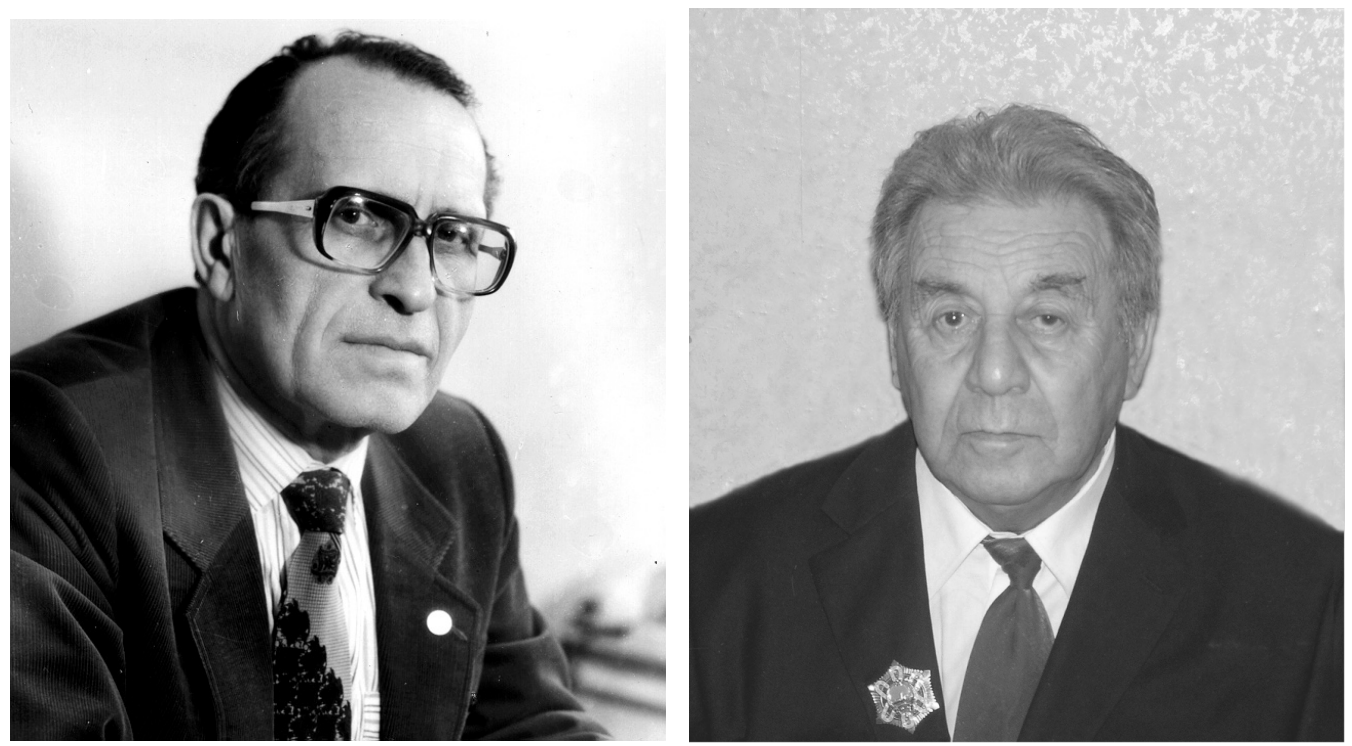

Рис. 2. Чл.-корр. РАН, профессор Е.В. Пиннекер и д.-г.-м.н., профессор Б.И. Писарский.

Fig. 2. Prof. Pinneker E.V., Corresponding Member of RAS, and Prof. Pisarsky B.I., Doctor of Geology and Mineralogy.

сотрудников, из них 2 доктора и 6 кандидатов наук (рис. 3).

Под руководством д.г.-м.н.С.В. Алексеева коллектив лаборатории участвовал в реализации научных проектов «Массо- и энергообмен в подземной гидросфере Восточной Сибири и Монголии», «Модели эволюции природных, природно-техногенных гидрогеологических и инженерно-геологических систем в ре-

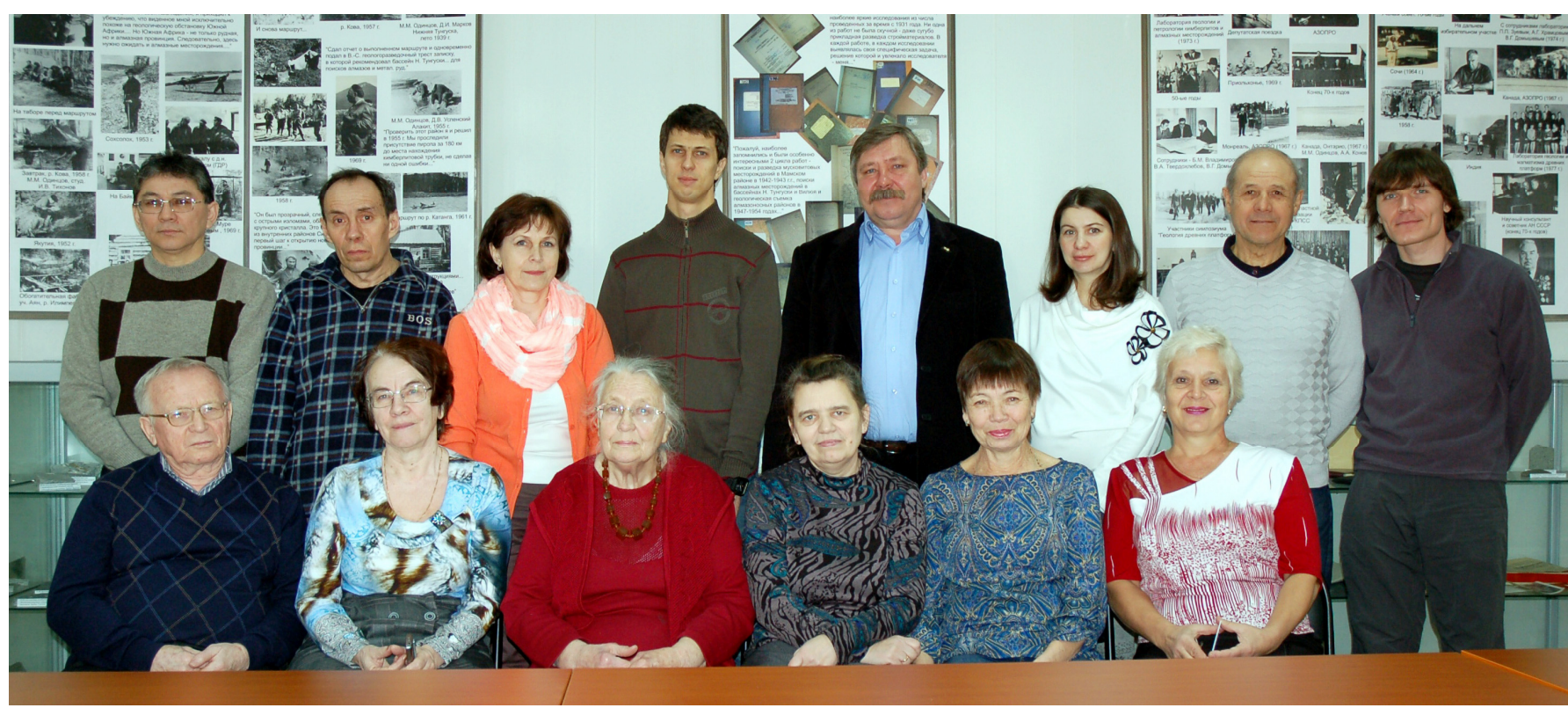

Рис. 3. Коллектив лаборатории гидрогеологии (2014 г.). В первом ряду, слева направо: к.г.-м.н. Ю.И. Кустов, В.А. Плешевенкова, А.Г. Томилова, Л.А. Дурбан, Л.А. Черных, И.Г. Крюкова. Во втором ряду, слева направо: П.С. Бадминов, А.И. Оргильянов, к.г.-м.н. Л.П. Алексеева, к.г.-м.н. А.М. Кононов, д.г.-м.н. С.В. Алексеев - зав. лабораторией, к.г.-м.н. М.А. Данилова, к.г.-м.н. С.Х. Павлов, П.А. Шолохов.

Fig. 3. The staff of the Laboratory of Hydrogeology in 2014 (left to right): $1^{\text {st }}$ row - Yu.I. Kustov, V.A. Pleshevenkova, A.G. Tomilova, L.A. Durban, L.A. Chernykh, I.G. Kryukova; $2^{\text {nd }}$ row - P.S. Badminov, A.I. Orgilianov, L.P. Alekseeva, A.M. Kononov, S.V. Alekseev (Head of the Laboratory), M.A. Danilova, S.Kh. Pavlov, P.A. Sholokhov. 


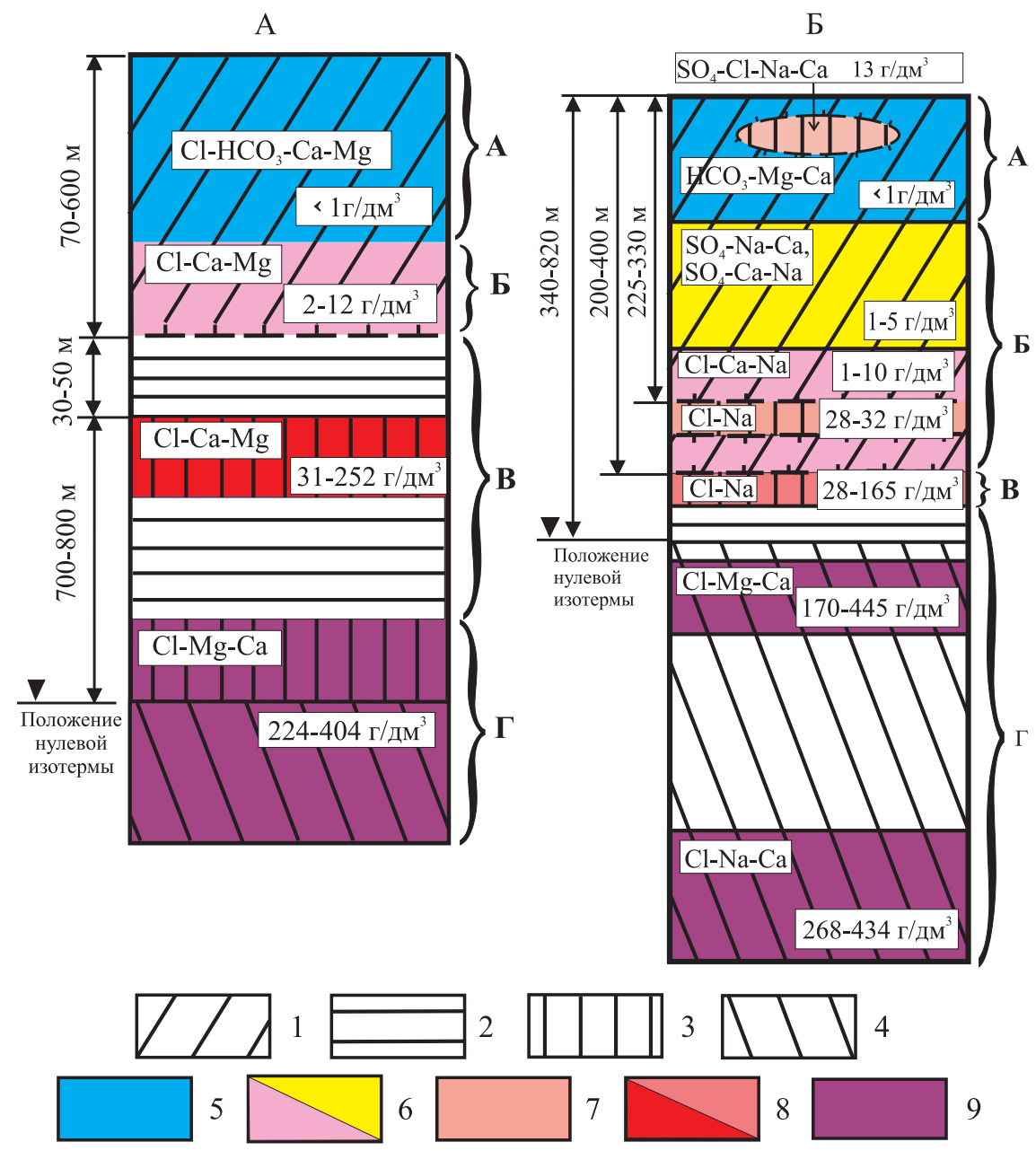

Рис. 4. Строение криолитозоны криогидрогеологических систем Якутской алмазоносной провинции (А - Оленек-Мархинской, Б - Вилюй-Ботуобинской).

1-4 - породы: 1 - мерзлые, 2 - морозные, 3 - охлажденные, 4 - с положительной температурой; 5-9 подземные воды: 5 - пресные в твердой фазе, 6 - солоноватые в твердой фазе, 7 - соленые внутри- и межмерзлотные, 8 - соленые, слабые и крепкие рассолы, 9 - крепкие и весьма крепкие рассолы.

Fig. 4. Cryolitic zones of cryohydrogeological systems of the Yakutian diamond-bearing province, the Republic of Yakutia (Sakha), Russia ( $A$ - Olenek-Markha; 5 - Vilyui-Botuoba).

1-4 - rocks: 1 - permafrost, 2 - frosted, 3 - with negative temperatures, 4 - with positive temperatures; 5-9 - underground waters: 5 - fresh in solid phase, 6 - salted water in solid phase, 7 - intra- and inter-permafrost salted water, 8 - salted water, weak and strong brine, 9 - strong and very strong brine.

гионах с контрастными климатическими условиями и геолого-структурной обстановкой», «Состояние геологической среды и подземной гидросферы Восточной Сибири в природных и техногенных условиях», «Природно-техногенные процессы в геологической среде и подземной гидросфере нефтегазоносных районов Восточной Сибири и сопредельных территорий».

В настоящее время усилия исследователей направлены на количественную оценку природных и техногенных процессов, происходящих в подземной гидросфере осадочных бассейнов Сибирской платформы и Байкальской рифтовой зоны в рамках Программы СО РAH VIII.73.3. «Эволюция гидрогеологических систем осадочных бассейнов Сибири» на 2013-2016 гг.

\section{2. ВАЖНЕЙШИЕ НАУЧНЫЕ РЕЗУЛЬТАТЫ ИССЛЕДОВАНИЙ ЛАБОРАТОРИИ ГИДРОГЕОЛОГИИ В 2009-2013 ГГ.}

\subsection{1. Пресные подземные воды}

Получены новые данные о гидрогеологических условиях надтрапповой части осадочного чехла на Верхнечонском нефтегазоконденсатном месторождении (рис. 4). В пределах верхней 500-метровой толщи выделены четыре основных водоносных комплекса отложений юры, среднего-верхнего и нижнего кембрия. Установлено, что основные ресурсы пресных подземных вод приурочены к карбонатно-терригенным породам верхоленской свиты среднего-верхнего кембрия. В 


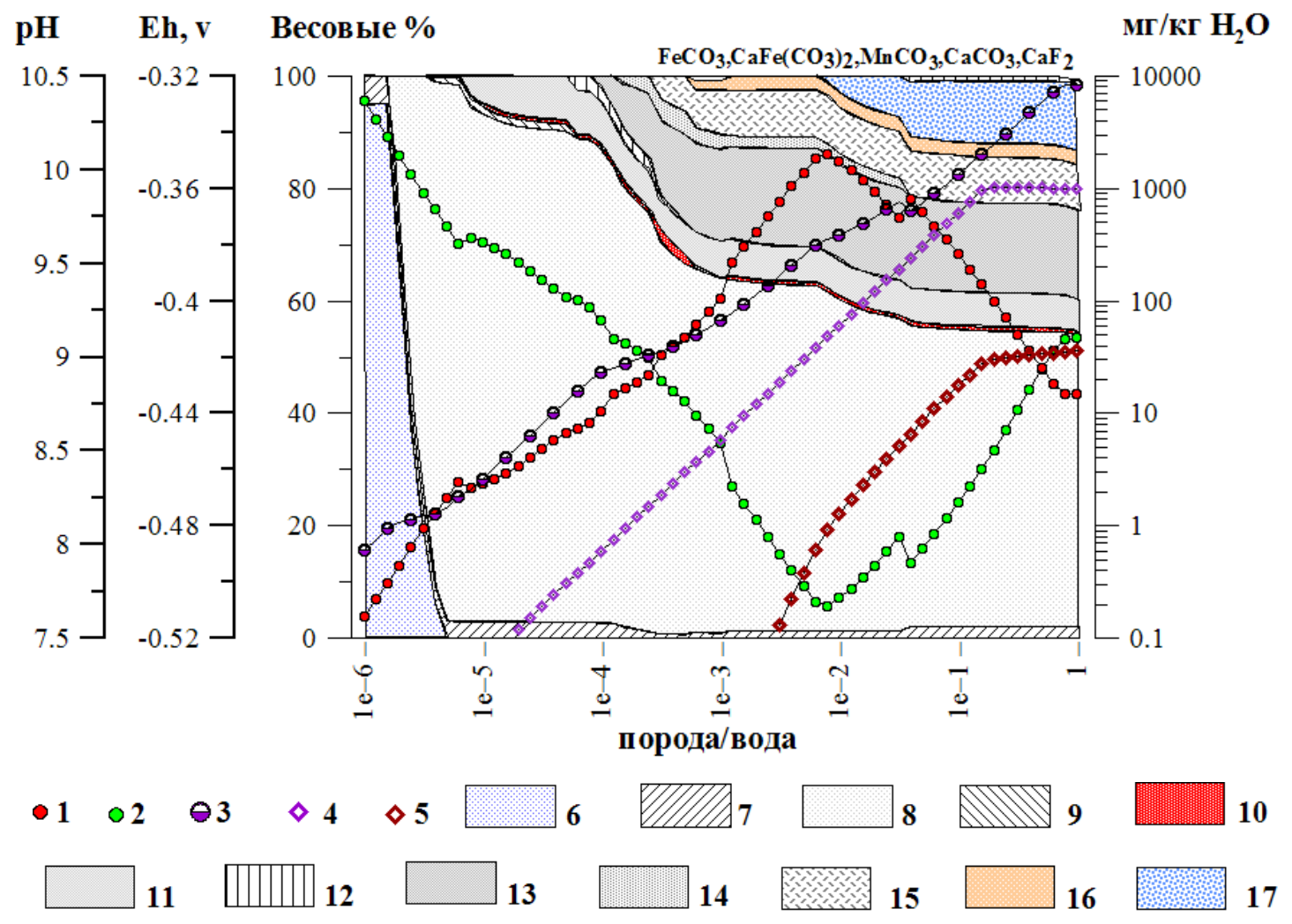

Рис. 5. Изменение основных гидрогеохимических характеристик азота и метана в зависимости от степени взаимодействия воды с алевролитом при $\mathrm{T}=45^{\circ} \mathrm{C}$ и $\mathrm{P}=80$ бар.

1 - pH; 2 - Eh; 3 - минерализация (мг/кг $\mathrm{H}_{2} \mathrm{O}$ ); содержание компонентов в воде (мг/кг $\left.\mathrm{H}_{2} \mathrm{O}\right): 4-\mathrm{CH}_{4}, 5$ - $\mathrm{N}_{2}$; твердая фаза (весовые \%): 6 - гиббсит, 7 - рутил, 8 - каолинит, 9 - магнетит, 10 - пирит, 11 - клинохлор, 12 - аннит, 13 - кварц, 14 - сфен, 15 - мусковит, 16 - анкерит, 17 - анальцим.

Fig. 5. Changes of main hydrochemical characteristics of nitrogen and methane depending on interaction between water and aleurolite at $\mathrm{T}=45^{\circ} \mathrm{C}$ and $\mathrm{P}=80$ bar.

1 - pH; 2 - Eh; 3 - salinity ( $\mathrm{mg} / \mathrm{kg}$ of $\mathrm{H}_{2} \mathrm{O}$ ); contents of components in water (mg/kg of $\mathrm{H}_{2} \mathrm{O}$ ): $4-\mathrm{CH}_{4}, 5-\mathrm{N}_{2}$; solid phase (weight \%): 6 - gibbsite, 7 - rutile, 8 - kaolinite, 9 - magnetite, 10 - pyrite, 11 - clinochlore, 12 - annite, 13 - quartz, 14 - sphen, 15 - muscovite, 16 - ankerite, 17 - analcime.

границах горного отвода на участке локализации стока сосредоточены ресурсы, равные $0.43 \mathrm{~m}^{3} / \mathrm{c}$, что составляет примерно 80 \% всего подземного стока лицензионного отвода. Все участки локализации при модуле 0.2 л/с·км² продуцируют не более 0.2 м $^{3} /$ с. С увеличением объема нефтедобычи и водоотбора для поддержания пластового давления при общей потребности, оцениваемой в 540 л/с, выявленные ресурсы окажутся достаточными только в годы высокой водности, которые фиксируются 2-4 раза в 10-12 лет. Таким образом, с наступлением маловодного периода неизбежно произойдет сработка ресурсов, возобновление которых будет возможно только в последующие годы большой водности.

По хлор-индикатору, эмиссия которого происходит из разнообразных поверхностных и подземных источников загрязнения, оценена уязвимость подземных вод. Хлор в количествах, превышающих в сотни раз фоновый уровень, установлен во всех типах водопунк- тов: поверхностных водах, родниках, скважинах. Разработаны два сценария изменения гидрогеодинамической обстановки: депрессивный (добыча подземных вод для поддержания пластового давления) и репрессивный (закачка подогретых вод в продуктивный пласт). По обоим сценариям происходят неблагоприятные изменения гидрогеохимической обстановки [Шенькман, 2013а, 2013б].

\subsection{2. Минеральные и термальные подземные воды}

Составлена карта минеральных лечебных вод Тункинской группы впадин Байкальской рифтовой зоны, частично охватывающая территорию гидроминеральных областей: Восточно-Саянской - углекислых холодных и термальных вод и Байкальской - азотных, углекислых и метановых термальных вод (рис. 5). На карте отображено распространение кристаллических пород горно-складчатого обрамления и межвпадинных 


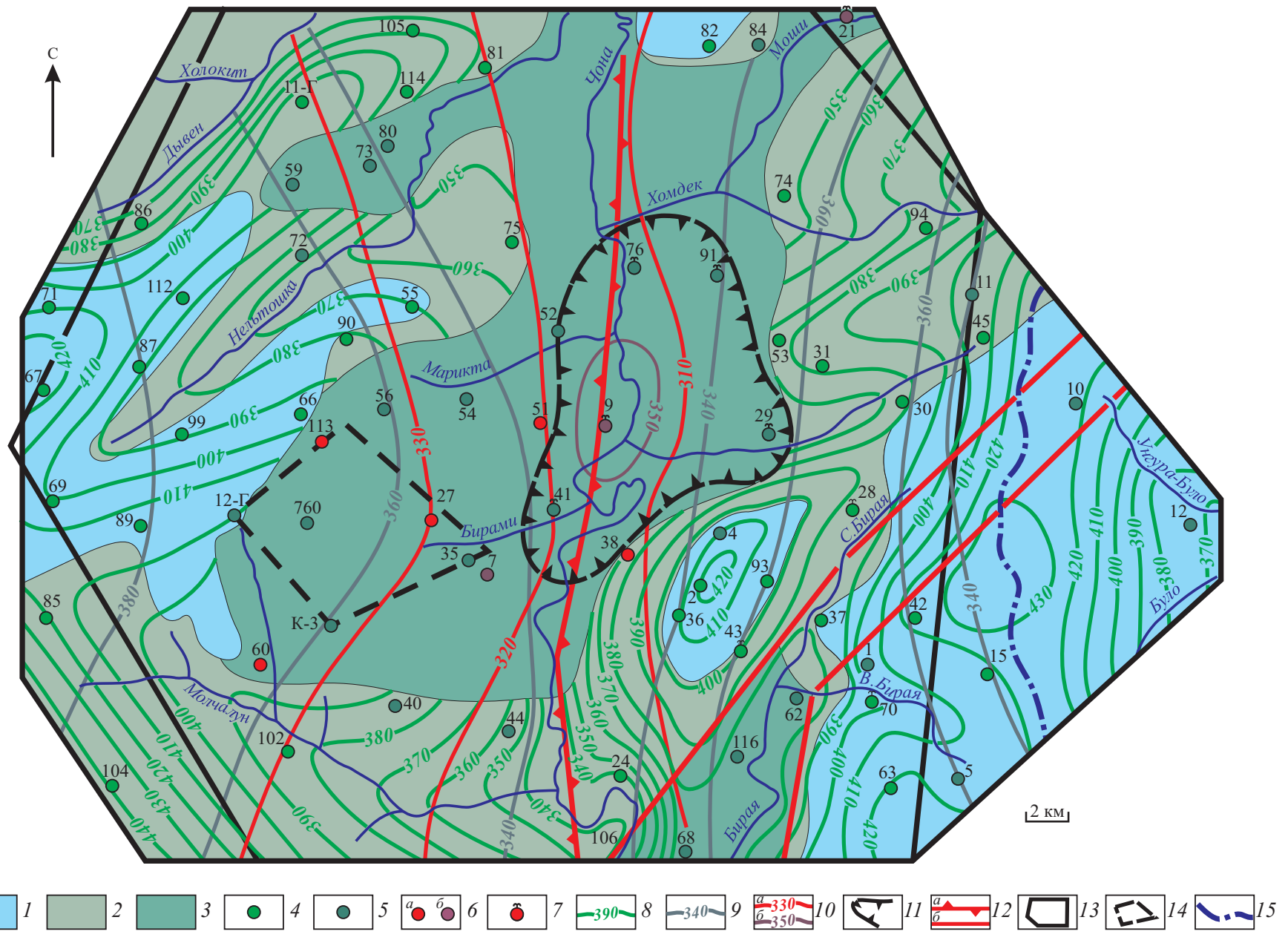

Рис. 6. Распространение водоносных комплексов на Верхнечонском нефтегазоконденсатном месторождении.

1-3 - водоносные комплексы отложений: 1 - терригенных юрских, 2 - терригенных верхоленской свиты среднего-верхнего кембрия, 3 карбонатных литвинцевской свиты нижнего-среднего кембрия; 4-6 - скважины, вскрывшие воды: 4 - верхоленской свиты, 5 - литвинцевской свиты, 6 - ангарской свиты нижнего кембрия: а - в надтрапповом, б - в подтрапповом слоях; 7 - фонтанирующие скважины; 8-10 - уровенные поверхности водоносных комплексов: 8 - гидроизогипсы верхоленского; пьезоизогипсы: 9 - литвинцевского, 10 - ангарского: а - надтраппового, б - подтраппового; 11 - граница участка, где пьезоповерхность литвинцевского комплекса находится выше земной поверхности; 12 - разлом: а - водовыводящий; б - водопроводящий; 13 - граница лицензионного отвода; 14 - основной участок нефтедобычи; 15 - предполагаемый подземный водораздел верхоленского водоносного комплекса.

Fig. 6. Water-bearing complexes in the Verkhnechonskoe oil and gas field.

1-3 - water-bearing complexes of sediments: 1 - terrigenous of the Jurassic, 2 - terrigenous of the Upper Lena suite of the Upper-Middle Cambrian, 3 - carbonate of the Litvintsevskaya suite of the Upper-Middle Cambrian; 4-6 - wells with water in: 4 - the Upper Lena suite, 5 - the Litvintsevskaya suite, 6 - the Angarskaya suite the Lower Cambrian: a - in the layer above trappes, 6 - in the layer below trappes; 7 - wells with natural flow; 8-10 - levels of water complexes: 8 - the Upper Lena water table contour; piezometric contours: 9 - Litvintsevsky, 10 - Angarsky: a - above trappe, $\sigma$ - below trappe; 11 - boundary of the site where the piezometric contour of the Litvintsevsky complex is above the ground surface; 12 - fault: a - water extraction, 6 - water transfer; 13 - boundary of the license area; 14 - main oil production site; 15 - assumed underground watershed of the Upper Lena water-bearing complex.

перемычек, вулканогенных и терригенных пород осадочного чехла впадин; показаны проявления и месторождения минеральных вод: азотные, метановые, углекислые; радоновые, сероводородные, железистые; холодные, термальные; состав минеральных вод, состав растворенных газов по преобладающему компоненту, бальнеотерапевтически активный компонент и температура воды [Кустов, 2009].

В результате моделирования физико-химических процессов в системе «вода - алюмосиликатные осадочные породы» впервые прослежен механизм образования углеводородных и азотных газов в формирующихся гидрокарбонатных натриевых термальных водах, в реальных условиях распространенных в осадочной толще Тункинской впадины Байкальской рифтовой зоны (рис. 6).

Установлено, что образование азота и метана может происходить не только в результате биохимических, 


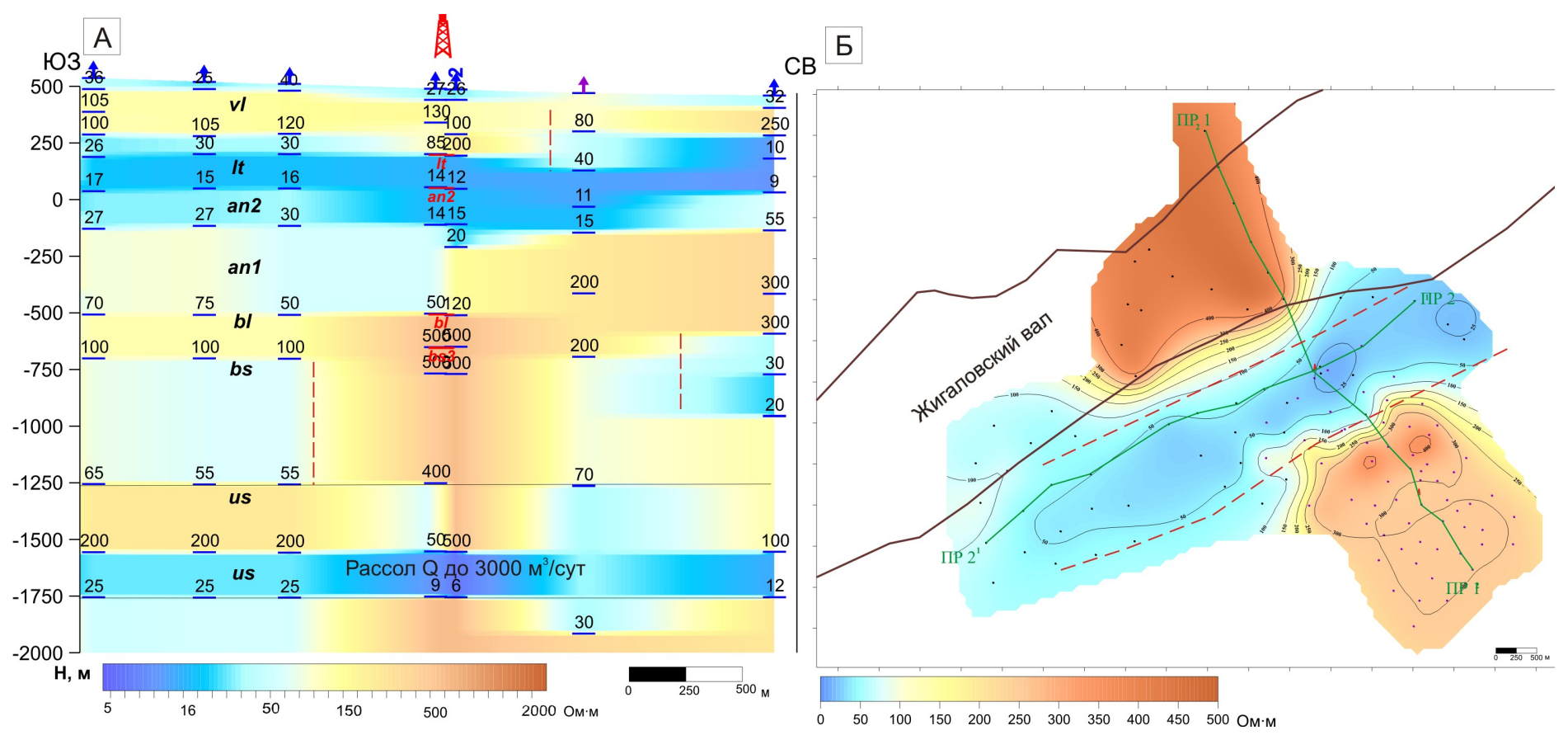

Рис. 7. Геоэлектрический разрез и схема продольного сопротивления горных пород усольской свиты нижнего кембрия юго-восточного крыла Жигаловского вала Сибирской платформы.

Fig. 7. The geoelectrical profile and the longitudinal resistance scheme of rocks in the Usolskaya suite of the Lower Cambrian in the south-eastern segment of the Zhigalovsky embankment of the Siberian platform.

термических и термокаталитических превращений органического вещества. Эти газы также образуются в породах, содержащих органическое вещество в процессе его гидролитического диспропорционирования. Соотношение между азотом и метаном в растворе зависит от формы углерода, содержащегося в осадочных образованиях, а устойчивый рост их содержания - от степени взаимодействия воды с породой. На основе полученных данных и результатов полевых гидрогеохимических исследований сформулирован принципиальный вывод о существовании в Тункинской впадине современной водонапорной системы с элизионным типом водообмена и седиментационном генезисе метановых термальных подземных вод, а не их инфильтрогенной или ювенильной природе [Павлов, Чудненко, 2011].

В системе «вода - гранит» определена стадийность аутигенного минералообразования, его роль в формировании кислотно-щелочного равновесия, окислительно-восстановительного потенциала, минерализации и состава растворов. Доказано, что в результате гидролитического воздействия воды на гранит, содержащий в своем составе летучие в кларковых концентрациях, могут сформироваться растворы, в которых анионы содержатся в количестве, фиксируемом в азотных термах, но при более высокой, редко встречающейся величине минерализации [Павлов, Чудненко, 2013a, 2013б].

\subsection{3. Промышленные подземные воды}

Созданы гидрогеологические и геолого-геофизические модели залегания глубоких поликомпонентных промышленных рассолов в разрезе осадочного чехла юга Сибирской платформы. Методом глубинной электроразведки (ЗСБ) по геоэлектрическим свойствам горных пород выявлены зоны низких (25-100 Ом·м) значений сопротивления, протягивающиеся с югозапада на северо-восток вдоль Жигаловского вала. На этой основе установлены закономерности локализации в плане и в разрезе рассолоносных зон, приуроченных к аномально проницаемым коллекторам в межсолевых карбонатных горизонтах галогенно-карбонатной гидрогеологической формации нижнего кембрия (рис. 7). В ходе бурения нефтеразведочной скважины на юговосточном крыле Жигаловского вала в интервале глубин 2040-2240 м вскрыты весьма крепкие хлоридные кальциевые рассолы с минерализацией 458 г/л и дебитом на изливе $3000 \mathrm{~m}^{3} /$ сут. Метод ЗСБ может успешно использоваться в комплексе геологоразведочных работ на стадии общих и детальных поисков глубокозалегающих металлоносных промышленных рассолов [Рябцев и др., 2013].

Получены новые данные о распространении и геохимических особенностях литиеносных подземных вод Иркутской области и Западной Якутии, выполнено таксономическое расчленение гидрогеологического 


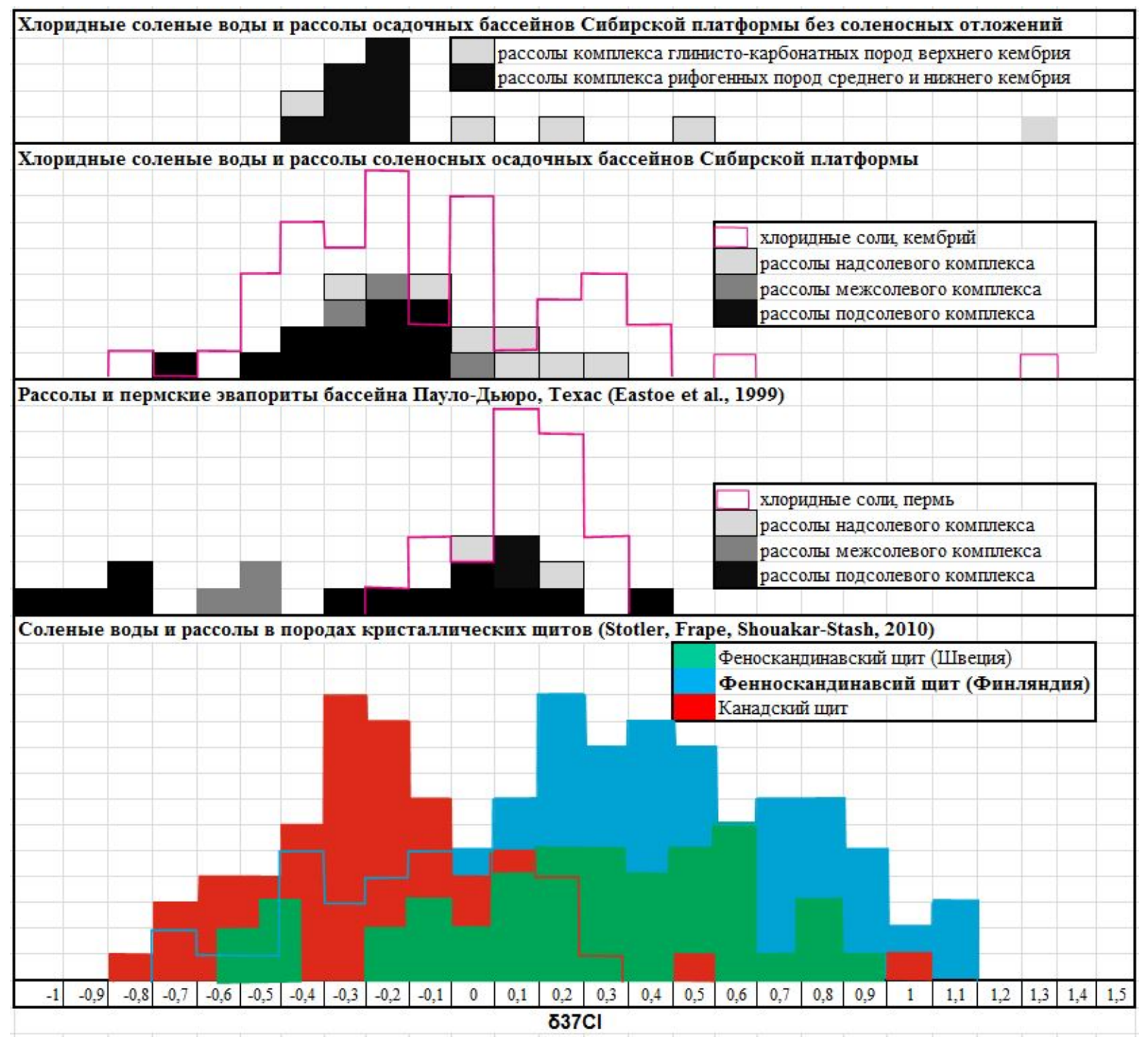

Рис. 8. Значения $\delta^{37} \mathrm{Cl}$ в соленых водах и рассолах осадочных бассейнов Сибирской, Северо-Американской и Южно-Американской платформ, а также Канадского и Фенноскандинавского кристаллических щитов.

Fig. 8. Values of $\delta^{37} \mathrm{Cl}$ in salted waters and brines of sedimentary basins located at the Siberian, North American and South American platforms and the Canadian and Fennoscandian crystalline shields.

разреза Сибирской платформы, и выделены перспективные рассолоносные зоны. Рассолы Сибирской платформы по концентрации лития сопоставимы с месторождениями (рапа озер) Цайдамской котловины Китая (Ситай и Дунтай) и Силвер Пик в США. Использование комплексной инновационной схемы переработки гидроминерального сырья Сибирской платформы позволит обеспечить производство соединений лития с низкой себестоимостью и вывести из стагнации литиевую отрасль России [Алексеев и др., 2012a, 2012б].

\subsection{4. Стабильные изотопы в подземных водах}

Выявлено распределение стабильного изотопа $\delta^{37} \mathrm{Cl}$ в соленых водах и рассолах осадочных бассейнов
Сибирской, Северо-Американской и Южно-Американской платформ, а также Канадского и Фенноскандинавского кристаллических щитов. Установлено, что для весьма крепких хлоридных кальциевых рассолов подсолевых и межсолевых водоносных комплексов осадочных бассейнов характерны наиболее низкие значения $\delta^{37} \mathrm{Cl}(-1.2 \ldots+0.4 \%)$, отражающие процессы испарительного концентрирования на ранних стадиях формирования маточной рапы (рис. 8). Хлоридные натриевые рассолы выщелачивания надсолевых водоносных комплексов в осадочных бассейнах, как правило, занимают промежуточное положение и в целом характеризуются небольшим диапазоном значений $\delta^{37} \mathrm{Cl}(-0.3 \ldots+0.5 \%)$ \% Особую группу образуют подземные воды с широким диапазоном значений $\delta^{37} \mathrm{Cl}$ и 
выраженным смещением в положительную сторону. K ним относятся седиментогенные хлоридные рассолы терригенно-карбонатных толщ $\left(\delta^{37} \mathrm{Cl}-0.3 \ldots+1.4 \%\right.$ \%, в формировании которых важную роль сыграли процессы диффузии и ионной фильтрации, а также рассолы кристаллических щитов $\left(\delta^{37} \mathrm{Cl}-0.78 \ldots+1.52 \%\right.$ с с более выраженным влиянием процессов взаимодействия в системе «вода - порода».

\subsection{5. Эволюция криогидрогеологических систем}

Определены основные этапы позднекайнозойской эволюции криогидрогеологических систем Якутской алмазоносной провинции в связи с динамикой климата, оледенениями и дегляциацией, регрессиями и трансгрессиями моря, изменением свойств горных пород и подземной гидросферы. Получены новые данные, и уточнены геокриологический (тепловое состояние горных пород, мощность, строение криолитозоны) и гидрогеологический (основные водоносные комплексы, гидрогеохимическая зональность, геохимические типы подземных вод) разрезы систем, разработана региональная схема криогенного метаморфизма подземных вод, выявлены ведущие факторы формирования их химического состава в зонах активного и затрудненного водообмена, выделен преобладающий тип техногенеза в ходе разработки месторождений алмазов (рис. 9). Созданные теоретические модели эволюции криогидрогеологических систем явились качественно новым звеном в теории развития мерзлых толщ и подземной гидросферы в четвертичном периоде [Алексеев, 2009].

\subsection{6. Геологическая среда}

На примере Шишкинской писаницы - особого объекта древнего наскального искусства Северной Азии, изученного с позиций геологического строения и закономерностей формирования склонов, впервые разработаны подходы к комплексному изучению археологических памятников и принципы информационного обеспечения их подготовки к музеефикации. Показана значимость геолого-геоморфологических особенностей массива скальных пород для обоснования относительного возраста плоскостей наскальной живописи [Мельникова и др., 2011].

Проекты лаборатории по планам НИР входят в число приоритетных направлений фундаментальных, ориентированных фундаментальных и прикладных исследований СО РАН, поддержаны грантами РФФИ, проводятся в рамках междисциплинарных интеграционных проектов и обеспечены хоздоговорами.

Научно-организационная деятельность лаборатории связана с работой Комиссии по изучению подземных вод Сибири и Дальнего Востока СО АН СССР (19591991 гг.), секции Сибири и Дальнего Востока Научного совета РАН по геоэкологии, инженерной геологии и гидрогеологии, проведением многочисленных региональных и всероссийских совещаний.

Сотрудники лаборатории работают в кооперации с лабораториями институтов СО РАН и вузами Иркутска, Красноярска, Новосибирска, Томска, Тюмени, Улан-Удэ, Читы, Якутска, тесно сотрудничают с учеными Германии, Канады, Китая, Монголии, США, Франции. Многие годы проводится подготовка специалистов высшей квалификации - кандидатов и докторов наук. Успешно работает совет по защитам докторских диссертаций по специальностям 25.00.07 гидрогеология и 25.00.08 - инженерная геология, грунтоведение и мерзлотоведение.

Перспективы дальнейшего развития лаборатории определяются наличием сложившейся и успешно развивающейся гидрогеологической школы, основателем которой является выдающийся исследователь подземной гидросферы Е.В. Пиннекер.

\section{3. ЭКЗОГЕОДИНАМИКА ЮГА ВОСТОЧНОЙ СИБИРИ и МОНГОЛИИ}

\section{1. КРАТКАЯ ИСТОРИЧЕСКАЯ СПРАВКА}

Лаборатория инженерной геологии и геоэкологии. Направление инженерной геологии, идейным организатором которого являлся М.М. Одинцов, развивается в институте с 1949 г. У истоков инженерно-геологических исследований в Восточной Сибири стояли Г.Б. Пальшин (лаборатория динамики склонов), Е.К. Гречищев, В.И. Астраханцев (лаборатория геодинамики водохранилищ), Ф.Н. Лещиков (лаборатория мерзлотоведения и грунтоведения). Долгие годы руководителем инженерно-геологического сектора (с 1968 по 2004 г. заведующий лаборатории) был Ю.Б. Тржцинский, который и возглавил в 1995 г. при объединении лабораторий единую лабораторию инженерной геологии и геоэкологии (рис. 10). В период 2004-2005 гг. заведующим лаборатории был Г.И. Овчинников.

За прошедший исторический период были получены значимые научные результаты, оказавшие существенное влияние на социально-экономическое развитие Сибирского региона. Вышли в свет специализированные инженерно-геологические карты, выполнены научно-теоретические разработки по планированию и прогнозу положения береговой зоны водохранилищ Ангарского каскада ГЭС, выявлены региональные особенности развития основных экзогенных процессов Восточной Сибири, положено начало изучению лессовых грунтов региона. Результаты исследований обобщены в серии монографий: «Инженерная геология Прибайкалья», 1963, «Геология и сейсмичность зоны БАМ», 1985, «Братское водохранилище», 1963, и др.

Установлены основные закономерности формирования и распространения сезонно- и многолетнемерз- 

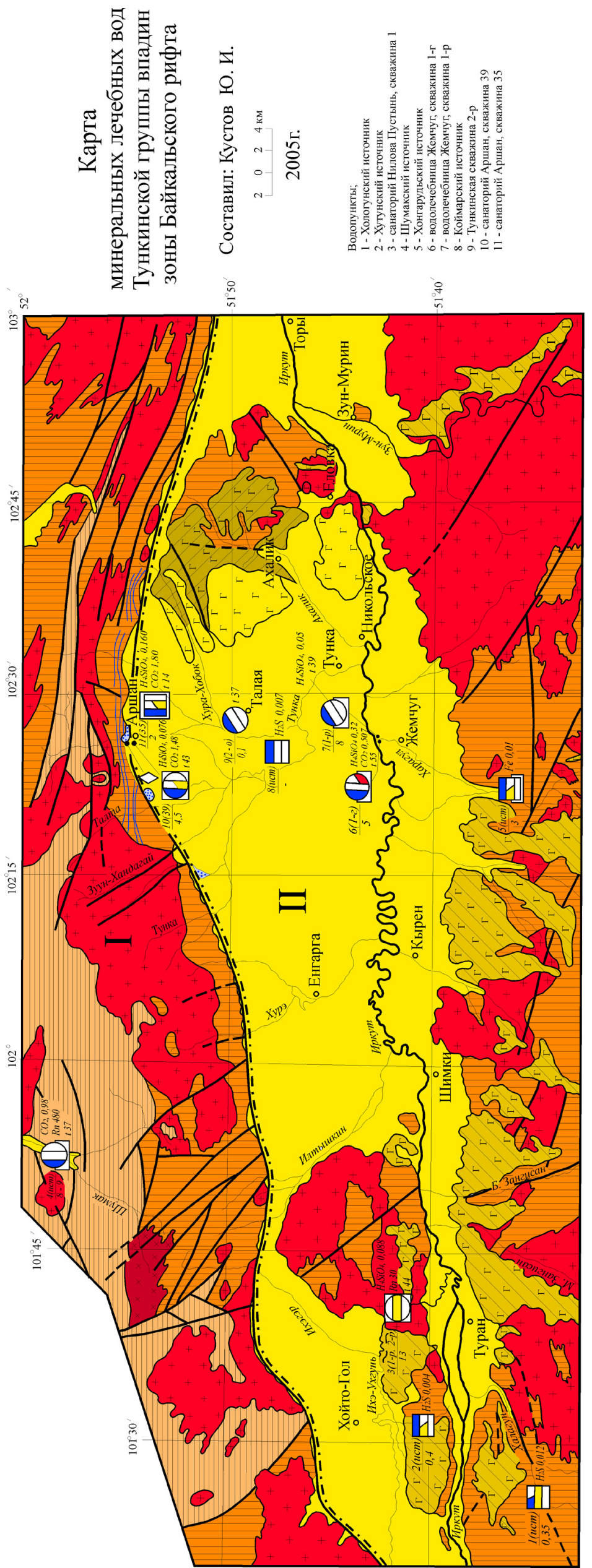
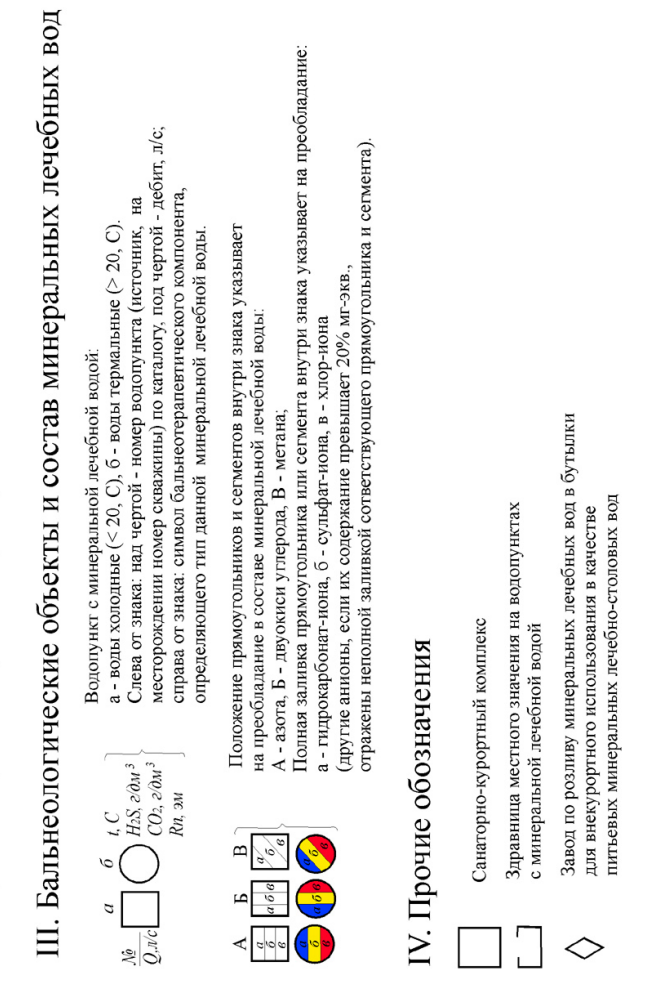


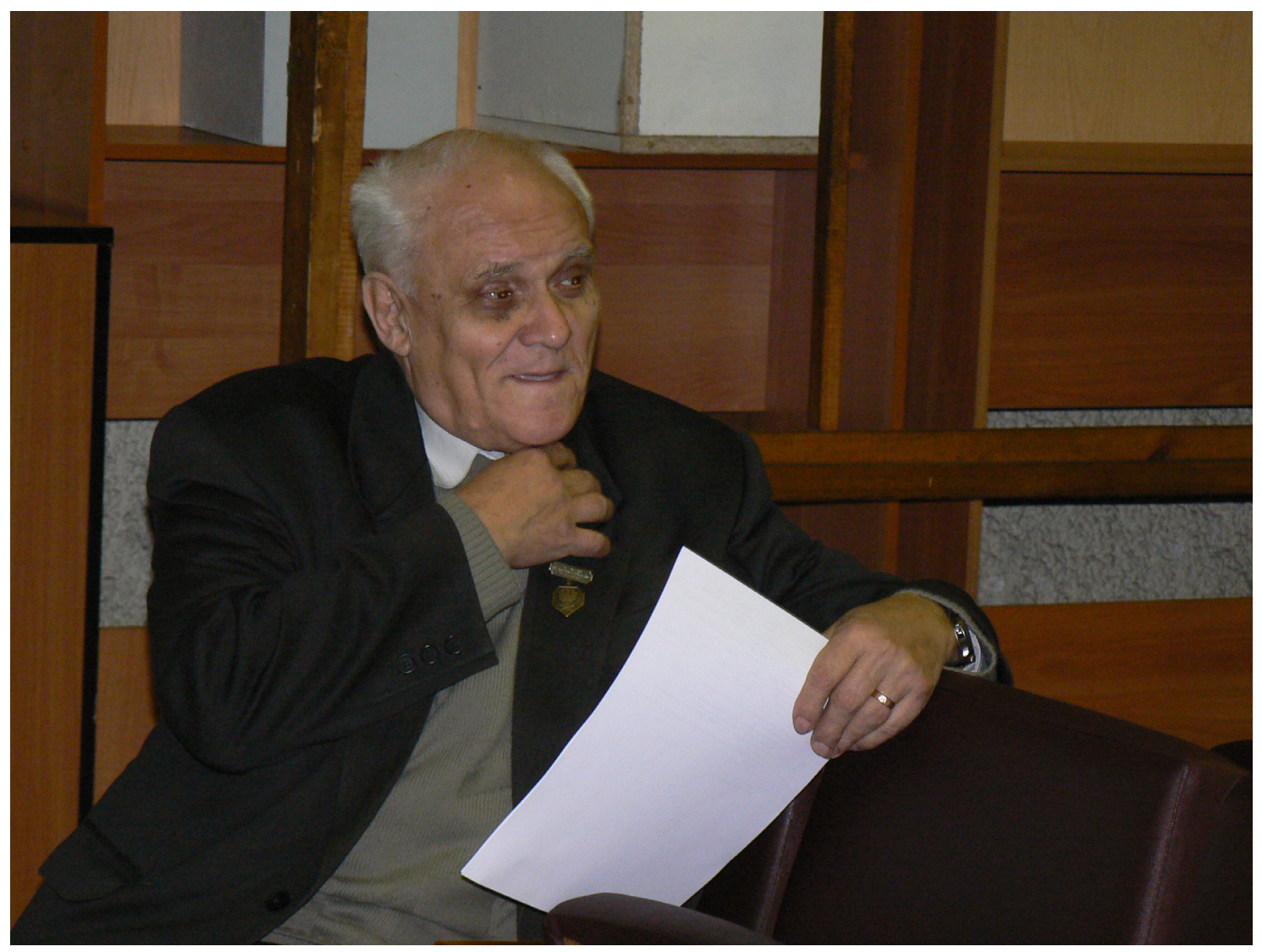

Рис. 10. Д.г.-м.н. Ю.Б. Тржцинский.

Fig. 10. Trzhtsinsky Yu.B., Doctor of Geology and Mineralogy.

лых пород юга Восточной Сибири, предложены принципы инженерно-геологического районирования, изучены микроструктуры глинистых и лессовых грунтов, исследованы их тиксотропно-реологические свойства. Выполнено теоретическое обобщение инженерно-геологических обстановок зон влияния Ангаро-Енисейского каскада ГЭС. Опубликованы монографии: «Проблемы охраны геологической среды (на примере Восточной Сибири)», 1993, «Изменение геологической среды в зонах влияния Ангаро-Енисейских водохранилищ», 1999, «Грунты юга Восточной Сибири и Монголии», 1998, «Современная экзогеодинамика юга Сибирского региона», 2006, «Экзогенные процессы в геологической среде. Оценка природных опасностей», 2008.

С 2006 г. лабораторию инженерной геологии и геоэкологии возглавляет Е.А. Козырева. В настоящее время в лаборатории трудятся: 1 доктор и 6 кандидатов наук, 1 н.с. без степени, 1 аспирант и 8 сотрудников инженерного состава (рис. 11). Научно-исследовательские работы проводились в рамках проектов: «Состояние геологической среды и подземной гидросферы Восточной Сибири в природных и техногенных условиях»; «Природно-техногенные процессы в геологической среде и подземной гидросфере нефтегазоносных районов Восточной Сибири и сопредельных территорий». В настоящее время реализуется научный проект «Экзогенные геологические процессы Монголо-Сибирского региона: факторы развития, современная динамика и степень опасности». Выполняются работы международного сотрудничества с Монголией, Польшей, Италией, Великобританией, США.

Научно-организационная деятельность лаборатории связана с участием в работах экспертных комиссий по вопросам геоэкологической безопасности, сотрудничеству с Министерством природных ресурсов Иркутской области. В 2013 г. по заказу Федерального агентства водных ресурсов проведена III Международная конференция «Создание и использование искусственных земельных участков на берегах и акватории водоемов». Исследовательские работы осуществляются в кооперации с коллегами из Тихоокеанского института географии ДВО РАН, Института географии РАН, Института водных и экологических проблем СО РАН, Национального исследовательского ИрГТУ, ИГУ. Современная инновационная направленность научных исследований обеспечена преемственностью в развитии знаний инженерно-геологического направления и научным потенциалом кадрового состава подразделения. 


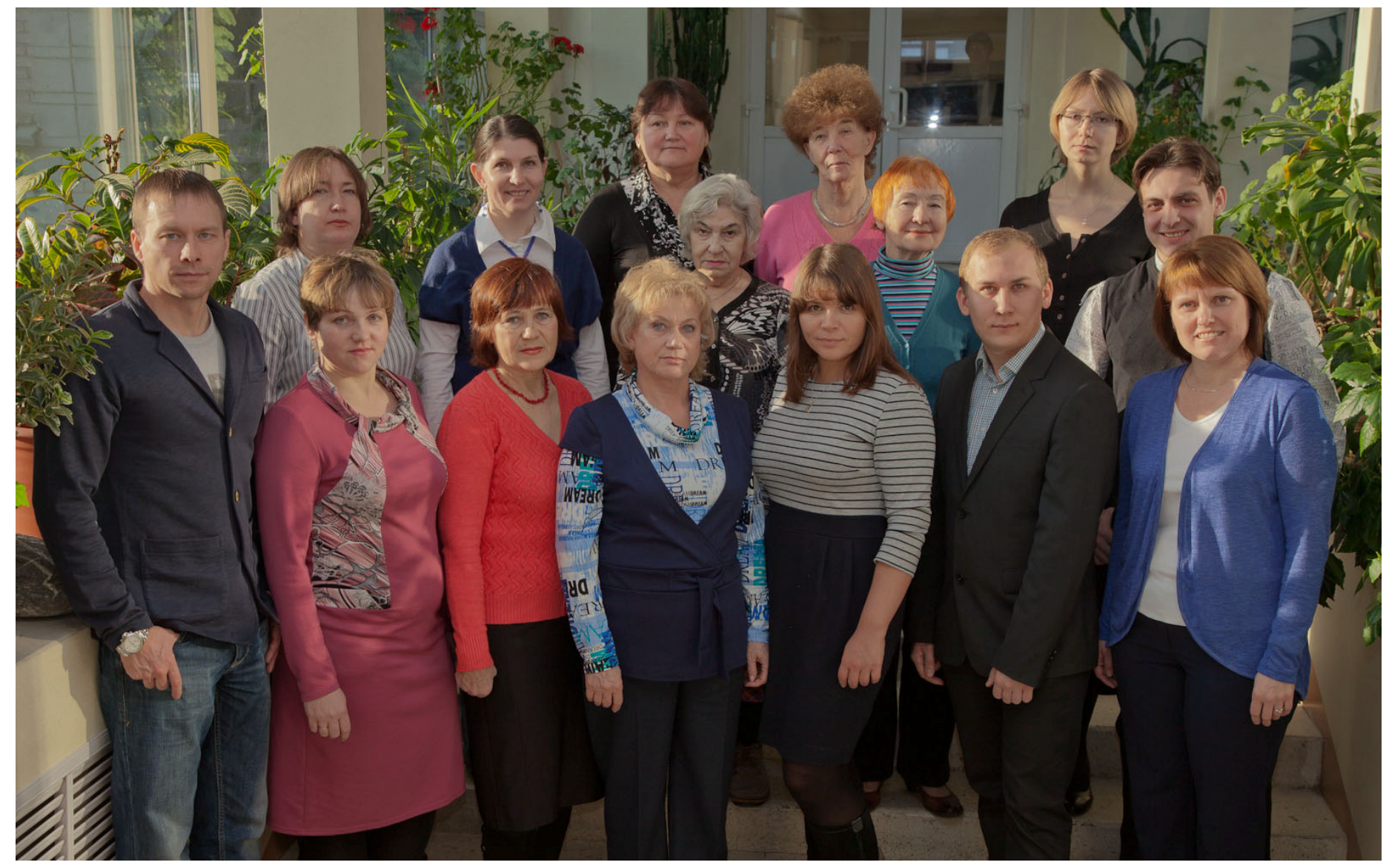

Рис. 11. Коллектив лаборатории инженерной геологии и геоэкологии.

Первый ряд: к.г.-м.н. А.А. Рыбченко, Ю.С. Тарасова, Л.Д. Баскакова, Т.В. Буддо, к.г.-м.н. А.В. Кадетова, В.А. Пеллинен, к.г.-м.н. Е.А. Козырева - зав. лабораторией. Второй ряд: М.В. Данилова, к.г.-м.н. О.А. Мазаева, к.г.-м.н. В.В. Акулова, В.В. Бехтерева, д.г.-м.н. Т.Г. Рященко, Г.И. Кустова, Е.В. Мартынюк, А.А. Светлаков.

Fig. 11. The staff of the Laboratory of Engineering Geology and Geoecology.

$1^{\text {st }}$ row - A.A. Rybchenko, Yu.S. Tarasova, L.D. Baskakova, T.V. Buddo, A.V. Kadetova, V.A. Pellinen, E.A. Kozyreva (Head of the Laboratory); $2^{\text {nd }}$ row - M.V. Danilova, O.A. Mazaeva, V.V. Akulova, V.V. Bekhtereva, T.G. Ryashchenko, G.I. Kustova, E.V. Martynyuk, A.A. Svetlakov

\section{2. ВАЖНЕЙШИЕ НАУЧНЫЕ РЕЗУЛЬТАТЫ ИССЛЕДОВАНИЙ ЛАБОРАТОРИИ ИНЖЕНЕРНОЙ ГЕОЛОГИИ И ГЕОЭКОЛОГИИ в 2009-2013 Гг.}

\subsection{1. Состояние геологической среды в условиях техногенеза}

Впервые для города Иркутска выполнен анализ механизмов развития экзогенных процессов, определена группа ведущих процессов, влияющих на формирование современного состояния геологической среды города. Не выявлено отличий в механизмах развития природных и природно-техногенных процессов, они схожи и определяются комплексом природных и техногенных факторов, что позволило определить техногенез как ведущий процессообразующий фактор на современном этапе эволюционного развития геологической среды города. Построенные электронные инженерно-геодинамические карты гравитационных, эрозионных, абразионных, суффозионно-просадочных процессов отражают вероятностно-площадное распространение процессов на территории города Иркутска и демонстрируют наиболее опасные участки с высоким риском деформаций зданий и сооружений (рис. 12). Установлено, что глубина трансформации геологической среды определяется природными особенностями вмещающих горных пород (морфология поверхности), свойствами геологической среды (структура и свойства отложений), а также степенью эволюции компонентов геологической основы и сочетанием различных техногенных факторов, проявляющихся как последовательно, так и одновременно. Использование инженерно-геологических карт с оценкой степени опасности экзогенных процессов для территории города способствует повышению геоэкологической безопасности при планировании городского пространства [Рыбченко и др., 2012; Козырева и др., 2012]. 


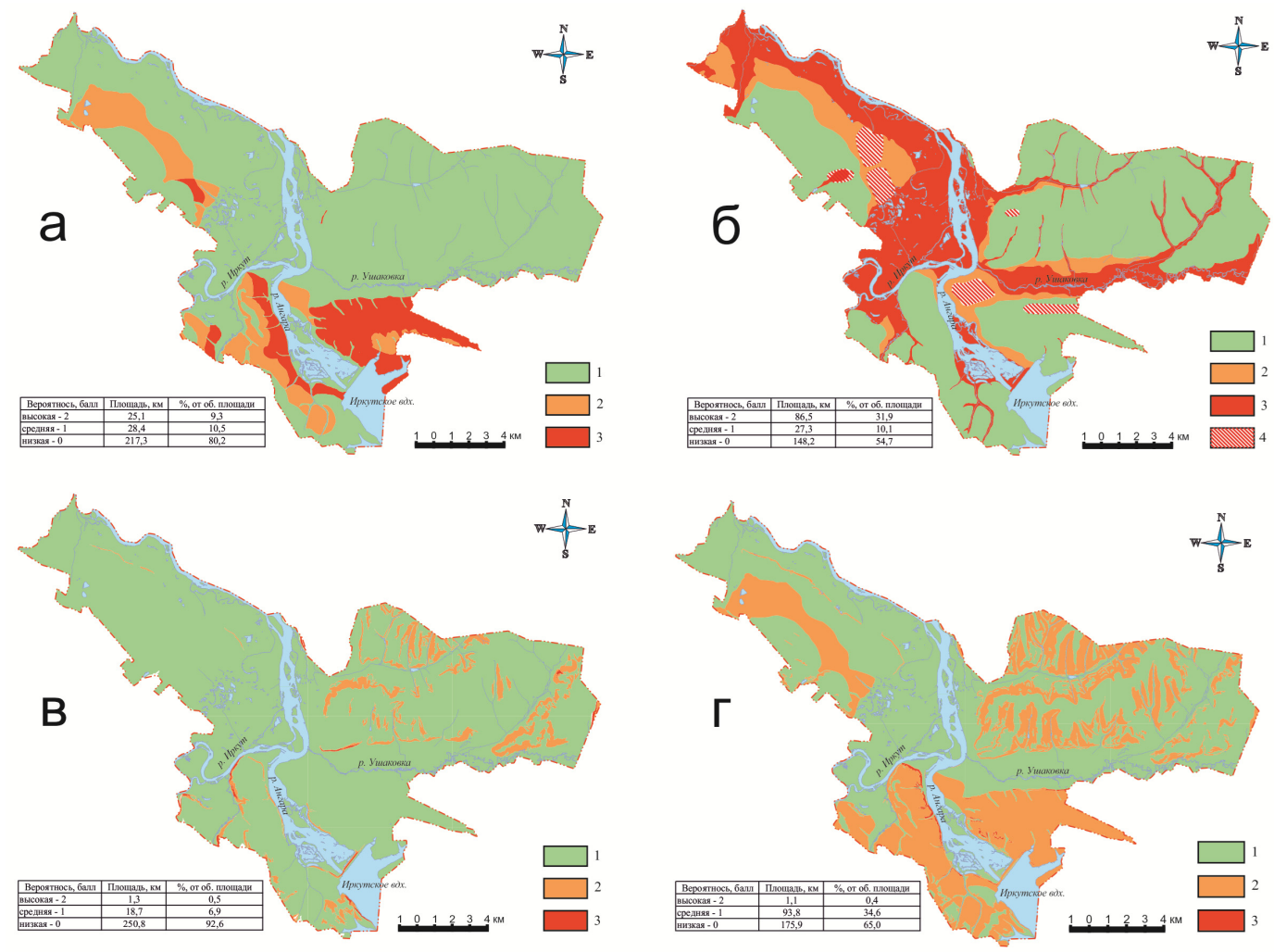

Рис. 12. Инженерно-геодинамические карты: $a$ - суффозионно-просадочного процесса; $\sigma$ - подтопления; 8 - эрозионного процесса; 2 - гравитационного процесса.

Вероятность развития процесса: 1 - высокая; 2 - средняя; 3 - низкая; 4 - техногенное подтопление.

Fig.12. Engineering geodynamics maps: $a$ - subsoil erosion and sinking; $\sigma$ - water flooding; $в$ - erosion; 2 - gravity process. Process development potential: 1 - high; 2 - medium; 3 - low; 4 - technogenic flooding.

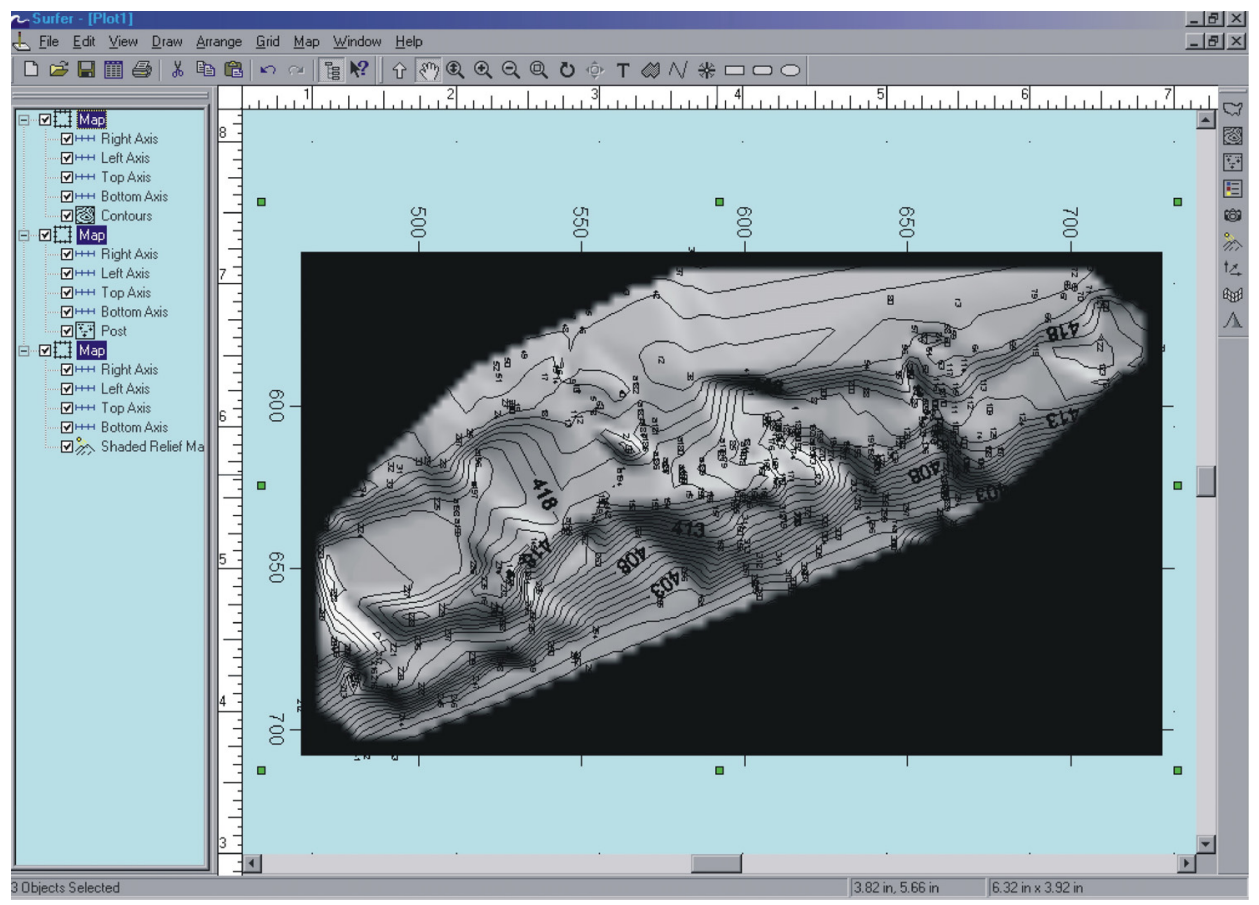

Рис. 13. Трехмерная модель локальной береговой геосистемы 2010 г. (юг Братского водохранилища).

Fig. 13. 3D model of the local bank geosystem, 2010. Location: the southern part of the Bratsk water reservoir. 


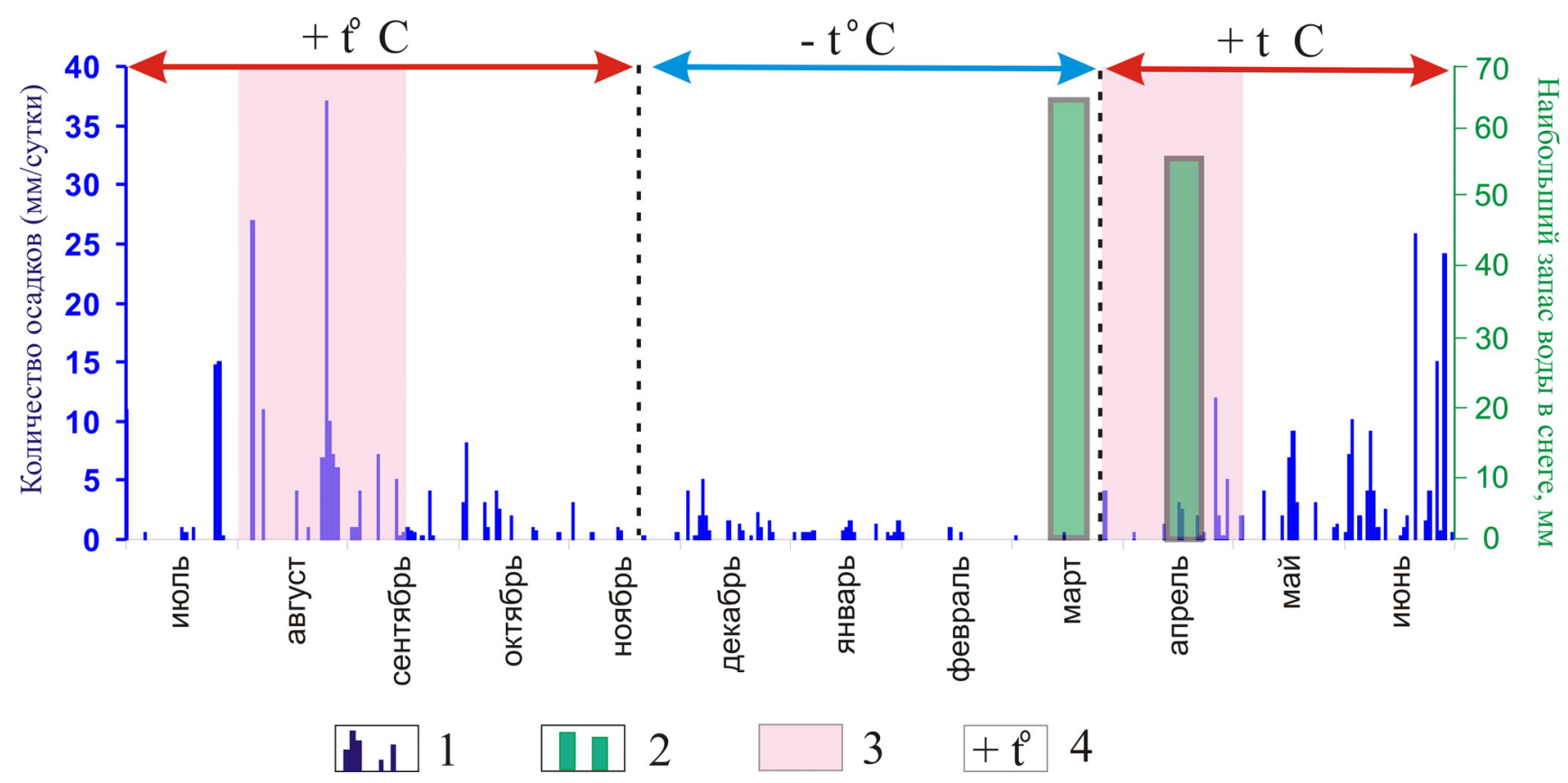

Рис. 14. Годовой цикл осадков и периоды активизации экзогенных процессов.

1 - суточное количество осадков; 2 - характеристика талого стока по запасам воды в снегах; 3 - период активизации экзогенных процессов; 4 - температура воздуха.

Fig. 14. The annual precipitation cycle and periods of activation of exogenous processes.

1 - daily precipitation; 2 - characteristics of snowmelt runoff by water and snow reserves; 3 - periods of activation of exogenous processes; 4 - air temperature.

\subsection{2. Природно-технические геосистемы - водохранилища}

Мониторинг развития экзогенных геологических процессов на ключевых участках юга Восточной Сибири позволил получить новые представления о развитии геологической среды в условиях техногенеза. На основе построения и сопоставления разновременных геодинамических моделей локальных береговых геосистем получена принципиальная модель трансформации береговых склонов вследствие влияния внешних факторов: природных (климатические) и техногенных (колебание уровня воды в водохранилище) (рис. 13).

Установлена последовательная смена механизма трансформации локальной геосистемы через синергетические эффекты (деформации) от совместного развития береговых процессов:

- взаимодействие процессов происходит постоянно, ведущий процесс изменяется во времени и контролируется воздействием внешнего фактора: природного или техногенного;

- оползневые и эрозионные процессы в пределах локальной геосистемы являются антагонистами, а их совместное развитие усиливает трансформацию берегового склона во времени;

- оползневая активность снижается в период низкого положения уровня воды, однако при повышении уровня устойчивость склона переходит в неустойчивое состояние вследствие абразии;

- активизация глубинной эрозии при понижении уровня воды в водохранилище, абразионный размыв берегового склона вызывают нарушение продольного профиля равновесия эрозионных форм, что способствует сохранению высокой динамики эрозионного процесса [Мазаева и др., 2011, 2014].

Полученная модель трансформации геосистемы позволяет в зависимости от заданного параметра внешнего фактора прогнозировать состояние берегового склона в схожих литолого-геоморфологических условиях побережья регулируемого водоема. На основе детального анализа характера распределения и количества атмосферных осадков как фактора образования оврагов и снижения устойчивости склона выявлены благоприятные временные периоды для развития деформаций: периоды талого (март - апрель) и ливневого (июль - сентябрь) стока (рис. 14). Впервые определены временные периоды активизации береговых процессов неволнового характера для водохранилищ Восточной Сибири [Mazaeva et al., 2013].

\subsection{3. Лессовый литогенез и техногенные литосистемы}

На основе принципов регионального грунтоведения предложена комплексная методическая схема лабораторных исследований грунтов, которая включает раз- 


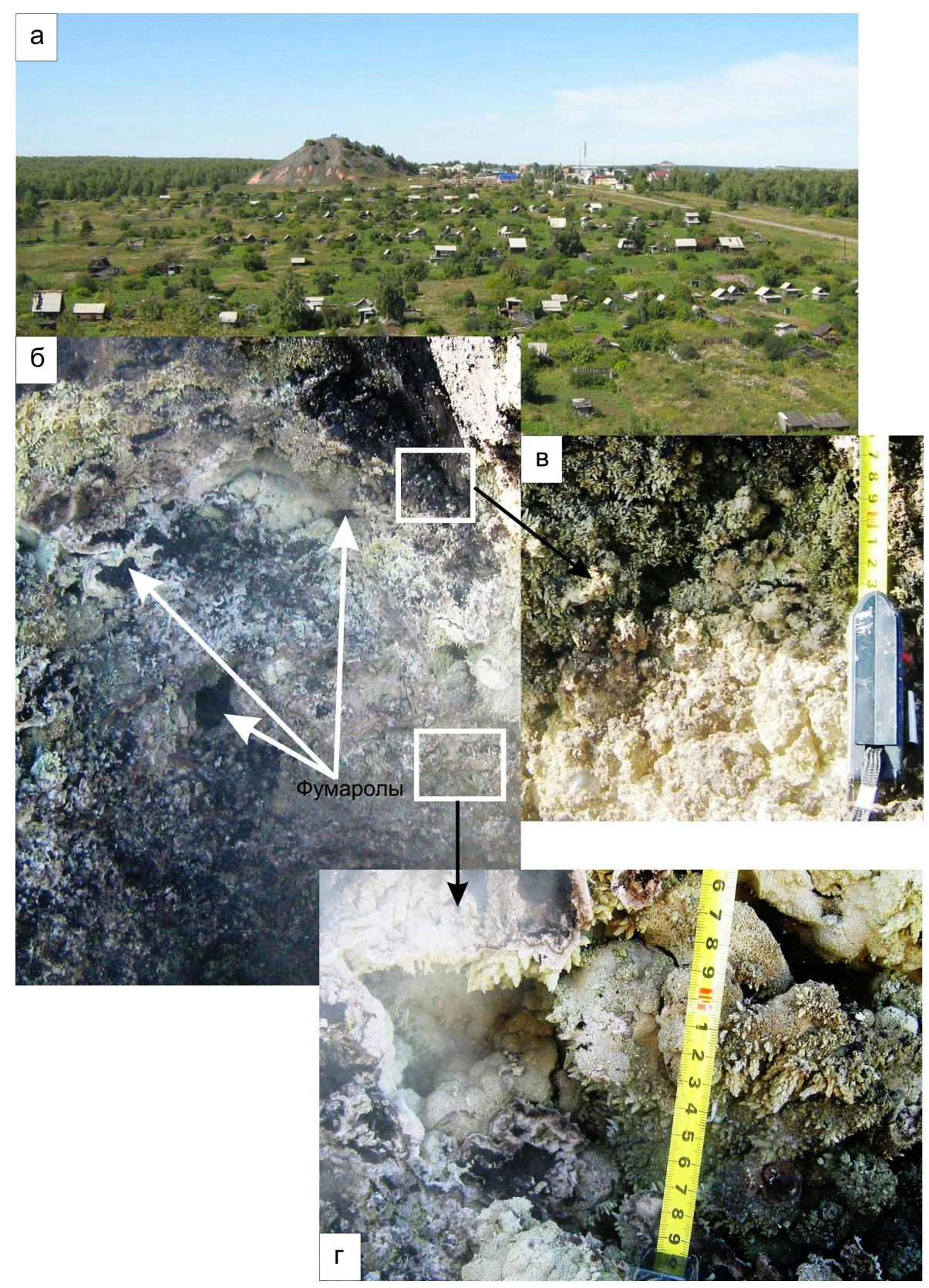

Рис. 15. Заброшенные дачные участки в районе терриконов Черемховского угольного месторождения в связи с высоким загрязнением почвы серой $(a)$.

На фрагментах отражены фумарольные зоны «дымящегося» террикона (б) с друзами (в) и почковидными (2) образованиями серы.

Fig. 15. Gardening land lots in the vicinity of gob piles of the Cheremkhovo coal deposit field, which are abandoned because the soil is highly contaminated with sulfur $(a)$.

Inserts show fumarole zones of the 'smoldering' gob pile (б) with sulfur druses (B) and nodules (2).

работанные методы «Микроструктура» и программный комплекс «Decompose» [Рященко, 2010]. На основе выявленных закономерностей формирования региональных проблемных грунтов (лессовых, глинистых и песчаных), которые обладают набором противоречивых свойств, предложен метод расчета интегрального индекса устойчивости территориальной системы «грунтовые толщи - природно-техногенные геологические процессы» к геодинамическим воздействиям [Рященко, 2013]. При изучении лессового литогенеза на территории юга Восточной Сибири установлена ведущая роль криогенного фактора на фоне интенсивной карбонатизации осадков, влияние геологического субстрата (характер распространения различных 


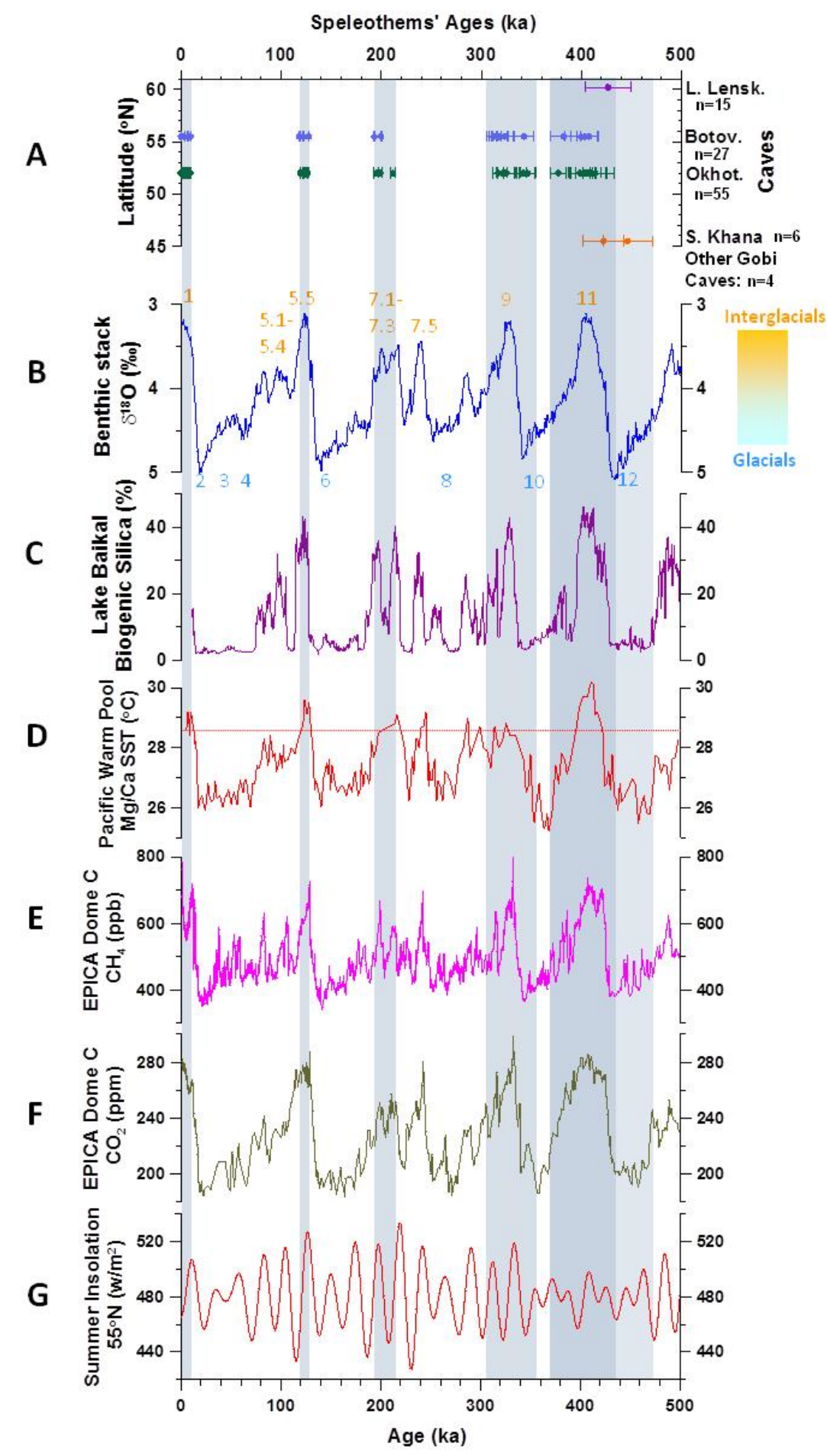

Рис. 16. A - распределение спелеотем U-Th возраста ( $\pm 2 \sigma)$ во времени и пространстве (n - общее количество датировок для каждой пещеры, в том числе за пределами U-Th диапазона). Серые вертикальные полосы показывают периоды роста спелеотем в Охотничьей и Ботовской пещерах. В - $\delta 180$ в бентосных фораминиферах океана с номерами MIS (морские изотопные стадии). C - концентрация биогенного кремнезема в донных отложениях озера Байкал (\%). D - сравнение температуры поверхности Тихого океана (SST - sea surface temperature) по соотношению Mg/Са с доиндустриальной температурой позднего голоцена (SST показана красной пунктирной линией). E и F - содержание $\mathrm{CH}_{4}$ и $\mathrm{CO}_{2}$ в записи кернов с Антарктической станции Восток (ЕРІСА). G - летняя инсоляция при $55^{\circ} \mathrm{N}$.

Fig. 16. A - distribution of speleothems of U-Th age $( \pm 2 \sigma)$ in time and space $(n-$ total number of datings for each cave, including those outside the $U$-Th range). Grey vertical bands show periods when speleothems grew in the Okhotnichiya and Botovskaya caves. B $-\delta 180$ in benthic foraminifers of the ocean with MIS numbers. C - concentration of biogenic silicon oxide in bottom sediments of Lake Baikal (\%). D - comparison between the sea surface temperature (SST) of the Pacific ocean against Mg/Ca and the pre-industrial temperature of the Late Holocene (SST is shown by the red dotted line). E, $\mathrm{F}-\mathrm{Contents} \mathrm{CH}_{4}$ and $\mathrm{CO}_{2}$ in core samples from the Vostok station in Antarctica (EPICA). G - summer insulation at $55^{\circ} \mathrm{N}$. 


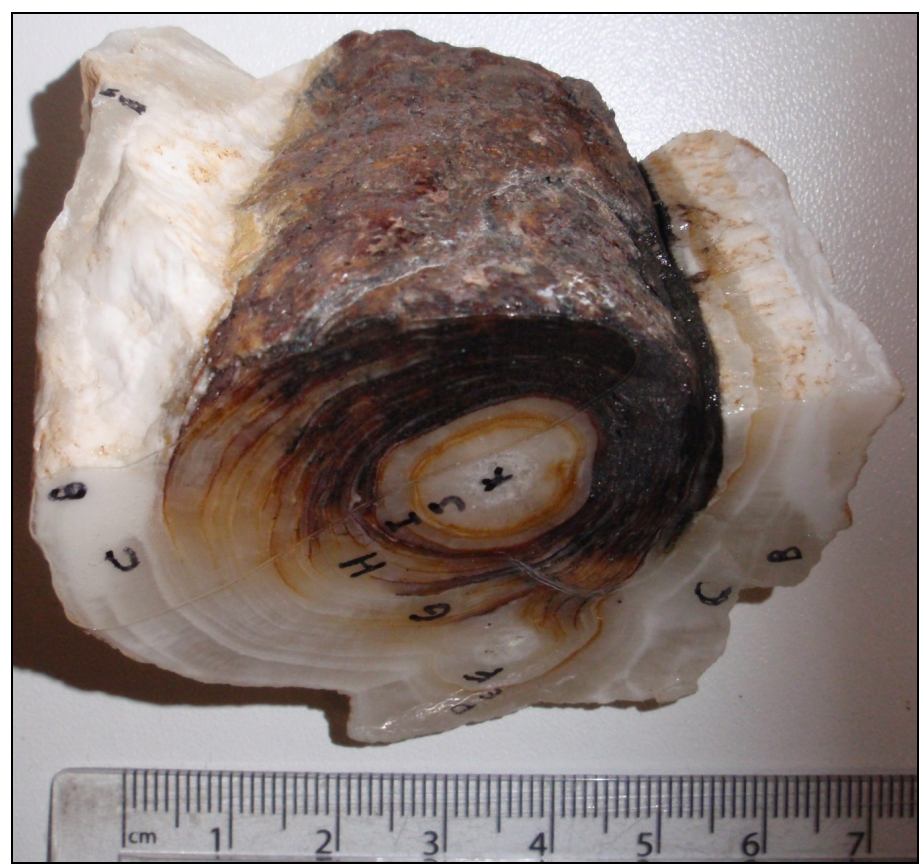

Рис. 17. Образец сталактита из Ботовской пещеры, анализируемый различными методами.

Fig. 17. A stalactite sample from the Botovskaya cave which is studied by various methods.

геологических формаций) и возможность развития этих процессов в голоцене, включая исторический период [Рященко и др., 2011, 2012].

По результатам изучения техногенных литосистем городских территорий юга Восточной Сибири получен фактический материал о техногенно-переотложенных юрских угленосных отложениях. Изученные терриконы и отвалы Иркутского угольного бассейна (рис. 15), свидетельствуют о широком спектре техногенного воздействия на окружающую среду и формировании отложений особого состава и состояния [Akulov et al., 2010; Jolivet et al., 2013].

\subsection{4. Эволюция природных систем Сибири и Монголии}

Выполнены датировки периодов роста спелеотем из пещер, расположенных по трансекту с юга на север
Монголо-Сибирского региона. Методом U-Th датирования определены периоды роста спелеотем, соответствующие термохронам за последние 500 тыс. лет. Установлено, что для южной части Монголо-Сибирского региона отмечается частое чередование термохронов и криохронов, что отражено в структуре спелеотем пещер южной зоны, тогда как в северной зоне спелеотем моложе 400 тыс. лет не обнаружено, что свидетельствует о наличии единого длительного периода криохрона [Pacton et al., 2013]. Датированные периоды роста соответствуют основным палеоклиматическим обстановкам, установленным по другим источникам; в том числе по морским изотопным стадиям (MIS 1-11), по палеоклиматическим данным из донных отложений оз. Байкал. Сопоставление данных позволяет судить о достоверной связи между изменениями глобальной температуры, климата и особенностями существования многолетней мерзлоты (рис. 16). Сравнение данных с PWP SST (Sea Surface Temperatures of the Pacific Warm Pool) и прогнозные построения показали, что повышение глобальной температуры на $0.5-1.0^{\circ} \mathrm{C}$ по сравнению с доиндустриальным периодом позднего голоцена приведет к деградации областей прерывистой мерзлоты в Сибири и трансформации влажностных условий в южных районах (территория Монголии), а потепление на $\sim 1.5{ }^{\circ} \mathrm{C}$ до уровня MIS-11 приведет к существенной деградации мерзлоты на север до $60^{\circ}$ с.ш. и создаст более влажные условия в пустыне Гоби [Vaks, 2011, 2013].

\subsection{5. Генезис карстовых форм}

На основе многостороннего анализа сибирских сталактитов, включая микроскопию высокого разрешения, геохимию изотопов, лабораторные опыты по микробиологически вызванному выпадению в осадок минералов, установлено, что поверхность соприкосновения между слоями роста в сталактите несет биогенный изотопный след. Вместе с морфологическими данными это свидетельствует о том, что кальцитовые кристаллы образованы микроорганизмами (рис. 17). Уранториевое датирование показало плейстоценовый возраст образцов сталактита. Таким образом, выявлено биотическое и абиотическое происхождение кристаллов сталактита [Гутарева и др., 2009; Базарова, 2011].

\section{4. ЛИТЕРАТУРА ПО ТЕМЕ ИССЛЕДОВАНИЙ}

\section{1. МОНОГРАФИИ}

Алексеев С.В. Криогидрогеологические системы Якутской алмазоносной провинции. Новосибирск: Академическое изд-во «ГЕО», 2009. 320 с.

Джурик В.И., Серебренников С.П., Рященко Т.Г. и др. Районирование сейсмической опасности территории города Эрдэнэта. Иркутск: ИЗК СО РАН, 2011. 122 с.

Лапердин В.К., Качура Р.А. Геодинамика опасных процессов в зонах природно-техногенных комплексов Восточной Сибири. Иркутск: ИЗК СО РАН, 2010. 312 с. 
Лапердин В.К., Имаев В.С., Верхозин И.И., Качура Р.А., Имаева Л.П. Опасные геологические процессы на юге Якутии и сопредельных территориях. Иркутск: ИЗК СО РАН, 2011. 240 с.

Мельникова Л.В., Николаев В.С., Демьянович Н.И. Шишкинская писаница. Т. 1. История и методика изучения, проблемы музеефикации, описание петроглифов. Иркутск: ООО «Репроцентр А1», 2011. 426 с.

Рященко Т.Г. Региональное грунтоведение (Восточная Сибирь). Иркутск: ИЗК СО РАН, 2010. 287 с.

Szczypek T., Kozyriewa E.A., Rybczenko A.A., Chak W.A., Mazajewa O.A., Wika S. Wyspa Olchon na Bajkale. WNoZ UŚ, ISZ SO RAN, Sosnowiec-Irkuck, 2011. 54 p.

Szczypek T., Wika S., Snytko W.A., Chak W.A., Kozyriewa E.A. Obszary piaszczyste na Olchonie (Bajkał), WNoZ UŚ, ISZ SO RAN, Sosnowiec-Irkuck, 2012. 69 p.

\section{2. СТАТЬИ В ЗАРУБЕЖНЫХ ЖУРНАЛАХ}

Akulov N.I., Akulova V.V., Khudonogova E.V. Pyrogenic metamorphism of the carbonaceous rocks in the south of the Siberian platform // Coal Combustion Research. 2010. P. 219-234.

Alexeev S.V., Alexeeva L.P., Kononov A.M. Cryopegs of the Yakutian diamond-bearing province (RUSSIA) // Groundwater Quality Sustainability (IAH Selected Papers). 2012. P. 101-107.

Alexeev S.V., Alexeeva L.P., Kononov A.M., Shmarov G.P. New Opportunities to Effective Tailing Storage Operation (JSC "ALROSA", Russia) // Procedia Earth and Planetary Science. 2013. V. 7. P. 10-13. http://dx.doi.org/10.1016/j.proeps. 2013.03.021.

Badminov P.S., Ganchimeg D., Pisarsky B.I., Oyuntsetseg D., Orgilyanov A.I., Kryukova I.G., Zundui-Osor Ch. Special features of the forming of thermal waters of the eastern part of the Khangay neotectonic uplift // Вестник АН Монголии. 2009. T. 4. C. 64-70.

Chabaux F., Granet M., Larquer Ph., Riotte J., Skliarov Eu., Skliarova O., Alexeieva L., Risacher F. Geochemical and isotopic (Sr, U) variations of lake waters in the Ol'khon Region, Siberia, Russia: Origin and paleoenvironmental implications // Comptes Rendus Geoscience. 2011. V. 343. № 7. P. 462-470. http://dx.doi.org/10.1016/j.crte.2011.07.004.

Jolivet M., Arzhannikov S., Chauvet A., Arzhannikova A., Vassallo R., Kulagina N., Akulova V. Accomodating large-scale intracontinental extension and compression in a single stress-field: A key example from the Baikal Rift System // Gondwana Research. 2013. V. 24. № 3-4. P. 918-935. http://dx.doi.org/10.1016/j.gr.2012.07.017.

Kaczmarek Halina, Mazaeva Oksana A., Kozyreva Elena A., Khak Viktoria A. Stacjonarne badania procesów egzogenicznych w strefie brzegowej Zbiornika Brackiego (południe Syberii Wschodniej) // Landform Analysis. 2012. V. 19. P. 110-120.

Khak V.A., Kozyreva E.A. Changes of geological environment under the influence of anthropogenesis (by the example of south of East Siberia, Russia) // Zeitschrift für Geomorphologie. 2012. V. 56. № 2. P. 183-199. http://dx.doi.org/10.1127/ 0372-8854/2011/0064.

Levi K.G., Kozyreva E.A., Zadonina N.V., Chechelnitsky V.V., Gilyova N.A. Problems of induced seismicity and engineering geological protection of reservoirs of the Baikal-Angara cascade // Geodynamics \& Tectonophysics. 2013. V. 4. № 1. P. 13-36. http://dx.doi.org/10.5800/GT-2013-4-1-0089.

Pacton M., Breitenbach S.F.M., Lechleitner F.A., Vaks A., Rollion-Bard C., Gutareva O.S., Osintcev A.V., Vasconcelos C. The role of microorganisms in the formation of a stalactite in Botovskaya Cave, Siberia - paleoenvironmental implications // Biogeosciences. 2013. V. 10. P. 6115-6130. http://dx.doi.org/10.5194/bg-10-6115-2013.

Rahmonov O., Rzetala M., Rahmonov M., Kozyreva E., Jagus A., Rzetala M. The formation of soil chemistry and the development of fertility islands under plant canopies in sandy areas // Research Journal of Chemistry and Environment. 2011. V. 15. № 2. P. 823-829.

Vaks A., Gutareva O., Breitenbach S., Avirmed E., Kononov A., Osinzev A., Henderson G. Speleothem record of permafrost in Siberia and aridity in Mongolia during the Last 450 kyr. // Mineralogical Magazine: Goldschmidt Conference. 2011. 2057.

Vaks A., Gutareva O.S., Breitenbach S.F.M., Avirmed E., Mason A.J., Thomas A.L., Osinzev A.V., Kononov A.M., Henderson G.M. Speleothems Reveal 500,000-Year History of Siberian Permafrost // Science. 2013. V. 340. № 6129. P. $183-186$. http://dx.doi.org/10.1126/science.1228729.

\section{3. СТАТЬИ В ОТЕЧЕСТВЕННЫХ ЖУРНАЛАХ}

Алексеев С.В., Алексеева Л.П., Вахромеев А.Г., Владимиров А.Г., Волкова Н.И. Литиевые подземные воды Иркутской области и Западной Якутии // Химия в интересах устойчивого развития. 2012а. № 1. С. 27-33.

Алексеев С.В., Алексеева Л.П., Вахромеев А.Г., Шмаров Г.П. Литиеносные подземные воды Иркутской области и Западной Якутии // Горный журнал. 2012б. № 2. С. 8-13.

Алексеев С.В., Алексеева Л.П., Кононов А.М. Новые данные об изотопном составе $\left({ }^{18} \mathrm{O}\right.$ и $\left.{ }^{2} \mathrm{H}\right)$ подземных вод кимберлитовых полей (Западная Якутия) // Геология, поиски и разведка рудных месторождений. Известия Сибирского отделения секции наук о Земле РАЕН. 2013. № 2(43). С. 93-99.

Алексеев С.В., Кононов А.М., Алексеева Л.П., Шмаров Г.П. Перспективы эффективной эксплуатации бессточных хвостохранилищ Удачнинского ГОКа АК «АЛРОСА» // Горный журнал. 2009. № 6. С. 53-56. 
Аржанников С.Г., Алексеев С.В., Глызин А.В., Кулагина Н.В., Игнатова Н.В., Орлова Л.А. Динамика развития природной среды в конце плейстоцена и голоцене западной части Тоджинской впадины (Восточная Тува) // Геология и геофизика. 2010. Т. 51. № 2. С. 206-221.

Бадминов П.С., Ганчимэг Д., Оргильянов А.И., Крюкова И.Г., Оюунцэцэг Д. Оценка глубинных температур термальных источников Хангая и Восточного Саяна с помощью гидрохимических геотермометров // Вестник БГУ. Химия, физика. 2011. Вып. 3. С. 90-94.

Бадминов П.С., Иванов А.В., Писарский Б.И., Оргильянов А.И. Окинская гидротермальная система (Восточный Саян) // Вулканология и сейсмология. 2013. № 4. С. 27-39.

Базарова Е.П., Гутарева О.С., Кононов А.М., Ущаповская З.Ф., Нартова Н.В., Осинцев А.В. Минералы пещеры Охотничья (Байкальский регион, Иркутская область) // Спелеология и карстология. 2011. № 7. С. 5-14.

Базарова Е.П., Гутарева О.С., Кононов А.М., Ущаповская З.Ф., Нартова Н.В., Осинцев А.В. Минералы пещеры Охотничья (Байкальский регион, Иркутская область) // Спелеология и карстология. 2011. № 7. С. 5-14.

Бержинский Ю.А., Бержинская Л.П., Иванькина Л.И., Ордынская А.П., Саландаева О.И., Чигринская Л.С., Акулова B.B., Черных E.H. Оценка сейсмической надежности жилых и общественных зданий при землетрясении 27.08.2008 на Южном Байкале // Вопросы инженерной сейсмологии. 2009. Т. 36. № 1. С. 23-39.

Верхозина В.А., Верхозина Е.В., Писарский Б.И. Геоэкологическая оценка влияния антропогенного фактора на экосистемы рифтовых озер мира (на примере Байкала и Ньясы) // Проблемы региональной экологии. 2010. № 2. С. 913.

Гутарева О.С., Козырева Е.А., Тржцинский Ю.Б. Карст в природных и техногенно изменённых условиях на юге Восточной Сибири // География и природные ресурсы. 2009. № 1. С. 96-103.

Демьянович Н.И. Особенности формирования склонов, врезанных в отложения верхне-среднекембрийской терригенной красноцветной формации // Геоморфология. 2010. № 3. С. 32-40.

Демьянович Н.И. Оползни как один из факторов природного и техногенного риска на территории города Иркутска // Геоэкология. 2011. № 4. С. 354-361.

Джурик В.И., Серебренников С.П., Рященко Т.Г., Ескин А.Ю., Усынин Л.А., Брыжак Е.В., Батсайхан Ц., Дугармаа Т. Районирование сейсмической опасности г. Эрдэнэт на основе количественных характеристик колебаний грунтов при сильных землетрясениях // Сейсмостойкое строительство. Безопасность сооружений. 2010. № 2. С. 38-43.

Кадетова А.В., Козырева Е.А. Потенциальные природные опасности при проектировании и эксплуатации подвесной канатной дороги на горнолыжном курорте «Гора Соболиная», Южное Прибайкалье // География и природные ресурсы. 2013. № 1. С. 50-55.

Качура Р.А., Куклин А.С, Лапердин В.К., Тимофеев Н.В. Прогнозная оценка геологических опасностей и экологических рисков на Дулисминском месторождении углеводородов // Защита окружающей среды в нефтегазовом комплексе. 2009. № 7. С. 29-34.

Качура Р.А., Куклин А.С, Лапердин В.К., Тимофеев Н.В. Селеопасность Южного Прибайкалья (на примере руч. Сухого) // Известия Иркутского государственного университета. Серия «Науки о Земле». 2009. Т. 2. № 1. С. 86-104.

Качура Р.А., Куклин А.С., Лапердин В.К., Тимофеев Н.В. Геологические опасности в зоне освоения побережья озера Байкал на участке порт Байкал-пос. Култук // Вестник ИрГТУ, Науки о Земле. 2010. № 3 (43). С. 22-29.

Козырева Е.А., Рыбченко А.А., Мазаева О.А, Хак В.А., Кадетова А.В. Опасные инженерно-геологические процессы зоны влияния байкало-ангарской гидротехнической системы // ГеоРиск. 2012. № 3. С. 46-55.

Козырева Е.А., Рыбченко А.А., Тарасова Ю.С., Жентала М., Ягус А. Трансформации береговых зон водохранилищ в ходе эксплуатационного периода (Южное Приангарье, Верхнесилезский регион) // Вестник ИрГТУ. 2012. № 3 (62). C. 42-50.

Козырева Е.А., Рыбченко А.А., Щипек Т., Пеллинен В.А. Солифлюкционные оползни побережья острова Ольхон // Вестник ИрГТУ. 2011. № 4. С. 41-49.

Кустов Ю.И. Подземные минеральные воды в Тункинском регионе юго-западного фланга Байкальского рифта // Отечественная геология. 2009. № 2. С. 53-60.

Лапердин В.К., Имаев В.С. Геологические опасные процессы в зоне Байкальского рифта и сопредельных территорий // Вопросы инженерной сейсмологии. 2010. Т. 37. № 1. С. 40-55.

Лапердин В.К., Качура Р.А. Криогенные опасности в зонах природно-технических комплексов на юге Восточной Сибири // Криосфера Земли. 2009. т. XIII. № 2. С. 27-43.

Лапердин В.К., Качура Р.А. Анализ возникновения природно-техногенных рисков и геоэкологической нестабильности по трассам нефтегазопроводов на юге Якутии // Защита окружающей среды в нефтегазовом комплексе. 2012. № 9. C. 17-24.

Лапердин В.К., Качура Р.А. Природная нестабильность и геоэкологический риск по трассе продуктопровода (район г. Благовещенска) // Защита окружающей среды в нефтегазовом комплексе. 2013. № 8. С. 18-22.

Лапердин В.К., Кустов Ю.И., Качура Р.А. Факторы природной нестабильности и техногенных рисков на территории курорта Аршан (бассейн р. Кынгарги, Республика Бурятия) // Защита окружающей среды в нефтегазовом комплексе. 2010. № 4. С. 37-45.

Лапердин В.К., Юшкин В.И., Качура Р.А. Геоэкологические опасности от криогенных деформаций на объектах автозаправочных станций на юге Восточной Сибири // Защита окружающей среды в нефтегазовом комплексе. 2012. № 6. С. 32-37. 
Мазаева О.А., Хак В.А., Козырева Е.А. Оценка основных процессообразующих факторов развития экзогенных гелогических процессов в локальных продно-технических геосистемах (на примере участка Быково, Брасткое водохранилище) // Вестник ИрГТУ. 2011. № 2. С. 41-47.

Мазаева О.А, Хак В.А., Козырева Е.А. Эрозионно-оползневой тип взаимодействия в локальных береговых геосистемах (на примере Братского водохранилища) // Известия Иркутского государственного университета. Серия «Наук о Земле». 2012. Т. 5. № 1. С. 205-223.

Мазаева О.А., Хак В.А., Козырева Е.А. Мониторинг локальных береговых геосистем Братского водохранилища // Геоморфология. 2014. № 1. С. 75-80.

Оргильянов А.И., Крюкова И.Г., Бадминов П.С. Новые данные о минеральных источниках Хэнтэй-Даурского неотектонического поднятия // Вестник кафедры географии Восточно-Сибирской государственной академии образования. 2011. № 2(3). С. 36-43.

Оргильянов А.И., Малков Е.Э., Писарский Б.И., Бадминов П.С., Ганчимэг Д. Минеральные воды трансграничной (проектируемой?) особо охраняемой природной территории «Истоки Амура» // География и природные ресурсы. 2011. № 2. C. 46-61.

Павлов С.Х., Оргильянов А.И., Бадминов П.С., Крюкова И.Г. Фильтрационные утечки из золошлакоотвала и их взаимодействие с геологической средой // Известия Иркутского государственного университета. Серия «Науки о Земле». 2013. Т. 6. № 2. С. 1-10.

Павлов С.Х., Чудненко К.В. Происхождение и процессы формирования метановых вод Тункинской впадины // Известия Сибирского отделения Секции наук о Земле РАЕН. Геология, поиски и разведка рудных месторождений. 2011. № 2 (39). C. 1-7.

Павлов С.Х., Чудненко К.В. Физико-химические аспекты формирования азотных терм в системе «вода - гранит» // Известия Иркутского государственного университета. Серия «Науки о Земле». 2011. Т. 2. № 2. С. 1-15.

Павлов С.Х., Чудненко К.В. Исследование происхождения метановых и азотных термальных вод методом компьютерного моделирования // Известия Иркутского государственного университета. Серия «Науки о Земле». 2013. Т. 6. № 1. С. 133-146.

Павлов С.X., Чудненко К.В. Физико-химические взаимодействия в системе «вода-порода» в условиях формирования азотных терм // Известия Сибирского Отделения Секции наук о Земле РАЕН. Геология, поиски и разведка рудных месторождений. 2013а. № 1(42). С. 82-95.

Павлов С.Х., Чудненко К.В. Формирование азотных терм: моделирование физико-химических взаимодействий в системе «вода-гранит» // Геохимия. 2013б. № 12. С. 1090-1104.

Павлов С.Х., Чудненко К.В., Тржцинский Ю.Б. Формирование оползневых процессов в карбонатных и сульфатнокарбонатных породах: физико-химические аспекты, гидрогеологические и структурные особенности // Геоэкология. 2009. № 5. С. 1-11.

Пеллинен В.А. Принципы создания классификаций оползней: краткий обзор // Вестник ИрГТУ. 2012. № 8. С. 52-55.

Рыбченко А.А., Кадетова А.В., Козырева Е.А. Результаты использования трехмерных моделей при мониторинге абразионного участка «Солнечный» (Иркутское водохранилище) // Вестник ИрГТУ. 2012. № 4 (63). С. 61-67.

Рябцев А.Д., Коцупало Н.П., Вахромеев А.Г., Комин М.Ф. Поликомпонентные литиеносные рассолы Сибирской платформы - сырье многоцелевого назначения // Рациональное освоение недр. 2013. № 1. С. 40-47.

Рященко Т.Г. Типизация геологической среды при сейсмическом микрорайонировании территории г. Эрдэнэта (Монголия) // Известия ВУЗов. Геология и разведка. 2010. № 5. С. 71-78.

Рященко Т.Г., Акулова В.В., Ербаева М.А. Формирование лессовидных отложений Забайкалья (на примере ключевых участков) // География и природные ресурсы. 2012. № 4. С. 117-125.

Рященко Т.Г. Микроструктура и свойства дисперсных грунтов (опыт применения кластерного анализа) // Известия ВУЗов. Геология и разведка. 2013. № 3. С. 39-45.

Рященко Т.Г. Сценарий формирования циклично построенных грунтовых толщ (оригинальный комбинированный метод) // Вестник ИрГТУ. 2013. № 7 (78). С. 50-57.

Рященко Т.Г., Вашестюк Ю.В. Сравнительный анализ параметров микроструктуры глинистых и лессовых грунтов (программа «Стандартная статистика») // Вестник ИрГТУ. 2011. № 9. С. 64-72.

Рященко Т.Г., Вашестюк Ю.В. Сравнительная характеристика микроструктуры и глинистых минералов полигенетических лессовидных отложений и эоловых лессов // Вестник ИрГТУ. 2012. № 6. С. 43-48.

Рященко Т.Г., Ухова Н.Н., Слагода Е.А. Изучение проблемных геолого-литологических разрезов глинистых отложений с применением грунтоведческих критериев // Отечественная геология. 2009. № 4. С. 61-67.

Рященко Т.Г., Ухова Н.Н., Штельмах С.И. Геохимические критерии инженерно-геологической оценки дисперсных грунтов юга Восточной Сибири (методические аспекты) // Вестник ИрГТУ. 2011. № 2. С. 58-61.

Рященко Т.Г., Ухова Н.Н., Штельмах С.И. Сравнительный анализ геохимических особенностей лессовых пород юга Восточной Сибири и Беларуси // Отечественная геология. 2011. № 2. С. 82-86.

Рященко Т.Г., Ухова Н.Н., Штельмах С.И., Белянина Н.И., Белянин П.С. Гипотезы формирования бурых суглинков Приморья: ретроспектива и новый взгляд (Дальний Восток России) // Тихоокеанская геология. 2011. Т. 30 . № 3. C. 80-92.

Рященко Т.Г., Ухова Н.Н., Щетников А.А., Рыжов Ю.В. Глинистые минералы дисперсных грунтов МонголоСибирского региона (методы и прогнозы) // Отечественная геология. 2012. № 6. С. 56-65. 
Рященко Т.Г., Чернышова Ю.В. Методы изучения микроструктуры дисперсных грунтов // Вестник ИрГТУ. 2009. № 1. С. 34-38.

Рященко Т.Г., Чернышова Ю.В. Микроструктура и физико-химические свойства глинистых грунтов (опыт применения кластерного анализа) // Вестник ИрГТУ. 2010. № 4. С. 41-44.

Семенов Р.М., Имаев В.С., Смекалин О.П., Чипизубов А.В., Оргильянов А.И. Гелий в глубинной воде Байкала - предвестник землетрясений // Доклады АН. 2010. Т. 432. № 4. С. 533-536.

Семенов Р.М., Малевич Л.В., Оргильянов А.И., Смекалин О.П. Исследования по поиску краткосрочных предвестников землетрясений в Прибайкалье // Сейсмостойкое строительство. Безопасность сооружений. 2011. № 4. C. 43-46.

Скляров Е.В., Склярова О.А., Меньшагин Ю.В., Данилова М.А. Минерализованные озера Забайкалья и СевероВосточной Монголии: особенности распространения и рудогенерирующий потенциал // География и природные ресурсы. 2011. № 4. С. 29-39.

Склярова О.А., Скляров Е.В., Меньшагин Ю.В., Данилова М.А. Динамика формирования и рудогенерирующий потенциал минерализованных озер Забайкалья и Северо-Восточной Монголии // Химия в интересах устойчивого развития. 2012. № 1. С. 35-41.

Тимофеева С.С., Чемерис Н.В., Шенькман Б.М. Современное состояние поверхностных, подземных и сточных вод в зоне воздействия шламонакопителей Байкальского целлюлозно-бумажного комбината // Современные наукоемкие технологии. 2008. № 5. С. 213-219.

Шенькман Б.М. Ресурсы подземных вод Верхнечонского нефтегазоконденсатного месторождения // География и природные ресурсы. 2013а. № 3. С. 77-84.

Шенькман Б.М. Химия подземных вод Верхнечонского нефтегазоконденсатного месторождения (ВЧНГКМ) // Известия Иркутского государственного университета. Серия «Науки о Земле». 2013б. Т. 6. № 1. С. $206-222$.

Шенькман Б.М., Шолохов П.А., Шенькман И.Б. Железо и марганец в пресных подземных водах Иркутска // Вестник ИрГТУ. 2011. № 8. С. 76-83.

Шенькман Б.М., Шолохов П.А., Шенькман И.Б. Подтопление Иркутска грунтовыми водами // География и природные ресурсы. 2011. № 2. С. 54-61.

Шишелова Т.И., Самусева М.Н., Шенькман Б.М. Использование ЗШО в качестве сорбента для очистки сточных вод // Современные наукоемкие технологии. 2008. № 5. С. 220-222.
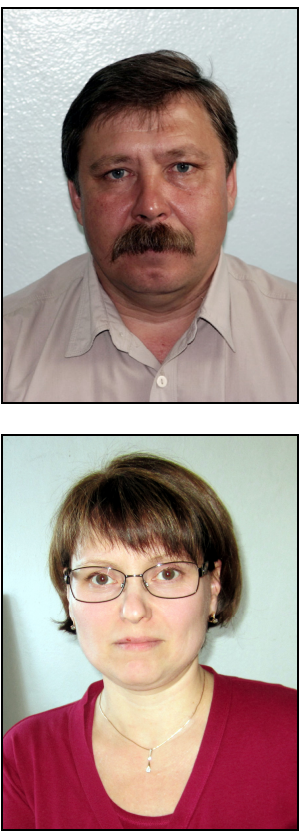

Алексеев Сергей Владимирович, докт. геол.-мин. наук, зав. лабораторией гидрогеологии Институт земной коры СО РАН

664033, Иркутск, ул. Лермонтова, 128, Россия

$\triangle$ e-mail: salex@crust.irk.ru

Alekseev, Sergei V., Doctor of Geology and Mineralogy, Head of Laboratory of Hydrogeology Institute of the Earth's Crust, Siberian Branch of RAS

128 Lermontov street, Irkutsk 664033, Russia

৫ e-mail: salex@crust.irk.ru

Козырева Елена Александровна, канд. геол.-мин. наук, зав. лабораторией инженерной геологии и геоэкологии Институт земной коры СО РАН

664033, Иркутск, ул. Лермонтова, 128, Россия

Тел.: (3952)425899; e-mail: kozireva@crust.irk.ru

Kozyreva, Elena A., Candidate of Geology and Mineralogy, Head of the Laboratory of Engineering Geology and Geoecology

Institute of the Earth's Crust, Siberian Branch of RAS

128 Lermontov street, Irkutsk 664033, Russia

Tel.: (3952)425899; e-mail: kozireva@crust.irk.ru 